يعتبر التعليم المعكوس هو الفكرة الرائجة هذه الأيام والتي ينادي بها الجميع، ابتداء من "بيل جيتس" المؤسس والرئيس التنفيذي السابق للشركة العملاقة مايكروسوفت، و "إيريك مازور" عالم الفيزياء الكبير والتزبوي ذي الثهرة العالمية، حيث

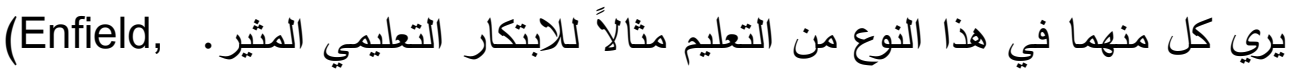
$r \cdot I r, i v)$ وتعد المراجعة من أهم المتغيرات الداخلية داخل الفصل المعكوس التي تعمل علي مسـاعدة الطـلاب علي فهم المـواد الدراسية المختلفـة حيث أظهرت الدراسـات العملية تفوق الطلاب الذين يقوموا بتدوين الملاحظات بأنواعها في أثناء الاستذكار علي هؤلاء الذين لا يفعلون ذلك حيث أن ممارسـة هؤلاء الطـلاب لعمليتي الترميز والتخزين (أي تدوين الأسئلة والملاحظات ومراجعتها) يساعدهم علي إستيعاب المادة (Kiewra, et al., 19^9; Kiewra et al., r. .0. (العلمية وفهمها وفي هذا الإطار يشير كلاً من (عدنان يوسف العتوم وآخرون، 0. . . ب، 9؛

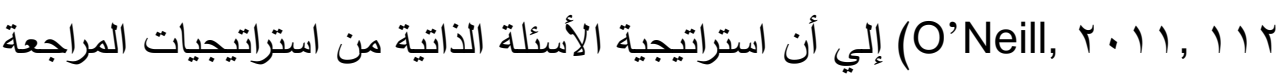
المهمة، فهي تُعد خطوة أكثر تقدماً نحو فهم التعلم، حيث يقوم فيها الطلاب بقراءة موضوع التعلم بدقة، وتحديد الأفكار الرئيسة به، وتحديد العلاقة بينها، ثم تحويلها إلي مجموعة من الأسئلة وكذلك فإن الإجابـة علي هذه الأسئلة قد تحث الطـلاب علي الئي البحث عن معلومات إضافية، فهي تمثل اختباراً ذاتياً لهم ليبين قدرتهم علي الفهم. وأكدت مجموعة من الدراسات على فاعلية استخدام الأسئلة الذاتية كاستراتيجية للمراجعـة في تحسين فهم المـواد الدراسـية، وأن عـادة يقوم أغلبيـة الطـلاب بتطبيـق أسلوب المراجعة في أثناء الاستذكار، مما يؤدي إلي تحسين جودة تعلمهم، ومن هذه Hui-Fang \& I-Ju, ؛Williams, الدراسات (King et al., 1997 199

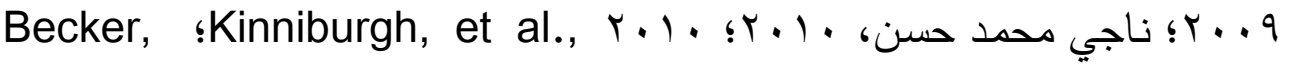


نمط المراجعة الاكترونية (فردي، ثنائي، جماعي) في بيئة الفصول أ. هنادي محمد أنور

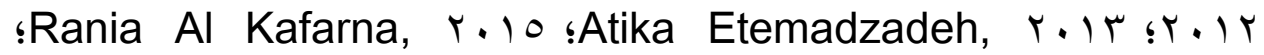

(Auliatisny Aziz\& Celly Yasin, Y. IV

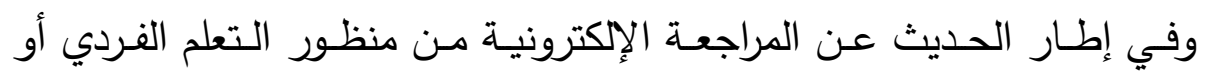

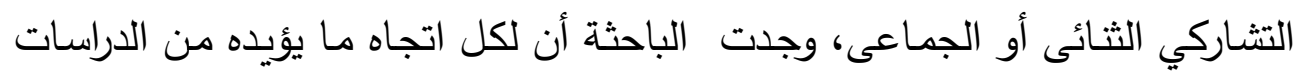

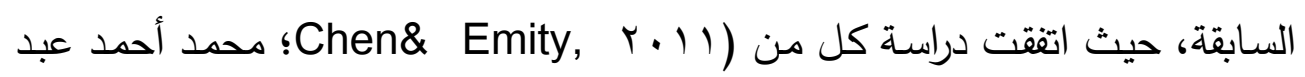

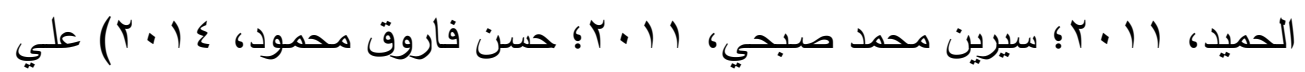
أن التفاعل الفردي غير التزامني عبر الويب له ما يبرره في بعض الأحيان حيث حيث يتيح هذا النمط للمتعلم عديد من المميزات منها علي سبيل المثال وليس الحصر :إتاحة

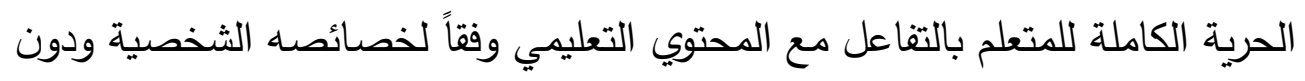
وجود أي عوائق زمنية أو مكانية بالإضافة إلي مساعدة المعلم علي مراجعة مشارئل الماركات

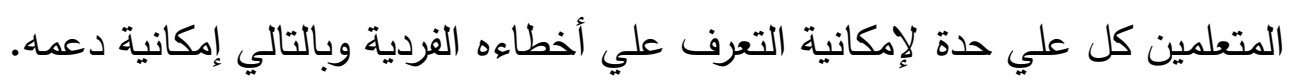

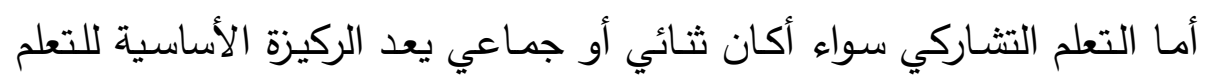

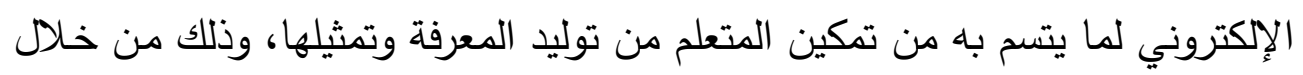

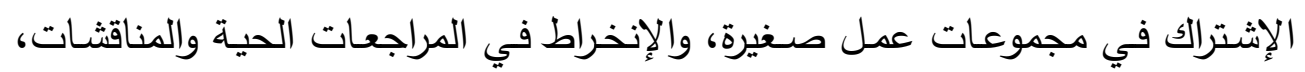

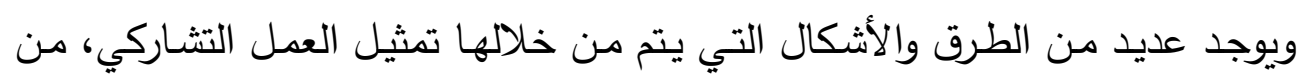

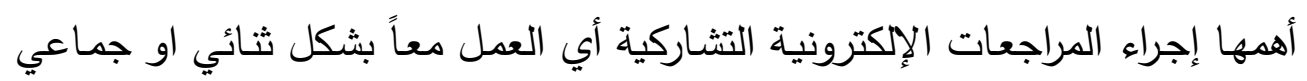

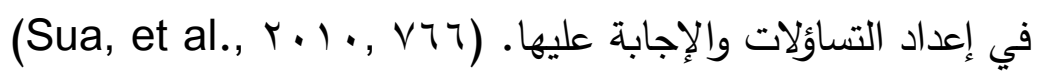

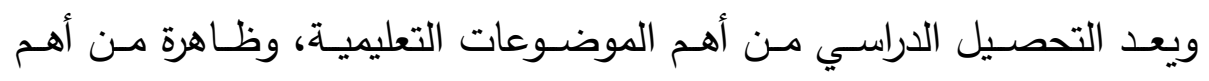

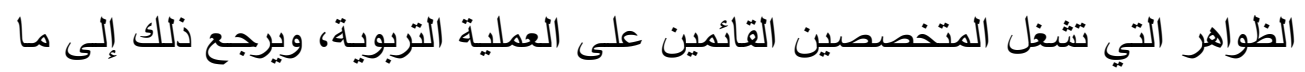

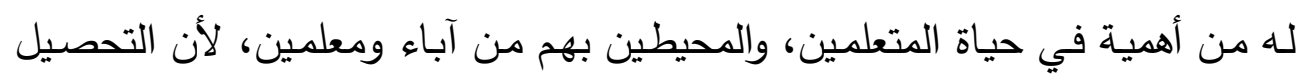

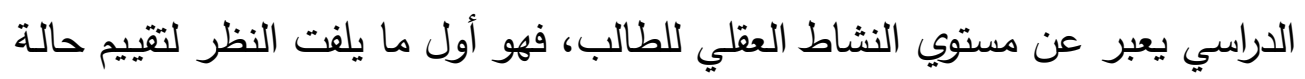
الطالب، وتحديد مساره التعليمي، بل وتحديد مراحل حياته كلها، وتوجيهـه التوجيـه 
السليم، وبذلك يلعب التحصيل الدراسي دوراً مهماً في تشكيل عملية التعلم وتحديدها

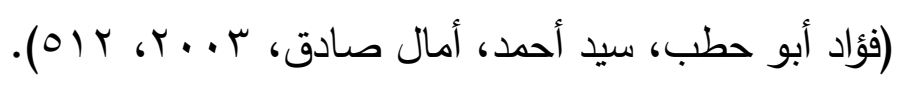

ويعد الأسلوب المعرفي (التعمق مقابل السطحية) أحد أهم الأسـاليب المعرفية

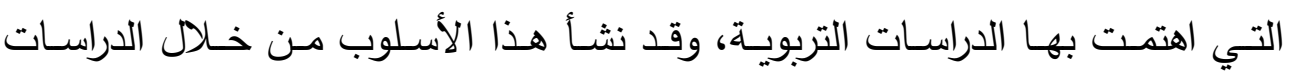
والأبحاث التي قام بها سكلسينجر (Schlesinger, 1901)، وحدده بأنـه المحافظة على السلوك الضيق، ويري (أنور محمد الشرقاوي، 990 (ا، با)، أن الفروق بين الأفراد في سعة وتركيز الانتباه إذ يتميز بعض الأفراد بالتعمق والتركيز على عدد من عناصر المجال في حين يتميز البعض الآخر من الأفراد بالفحص الواسع لعدد كبير من العناصر والمعلومات. هذا الاختلاف بين أسلوب التعلم (العميق/ السطحي) وأيهما أفضل أحد دوافع إجراء البحث الحالي لتحديد كيفيـة تصـيم المراجعـة الالكترنية داخل بيئة الفصـول المعكوسة لتناسب كليهما. من خلال ما سبق ونتيجة لإختلاف الآراء والنظريات حول تحديد أفضل نمط للمراجعات الإلكترونية ( فردي- ثنائي - جماعي) داخل بيئة الفصول المعكوسة، ومن هنا نبعت الحاجة لإجراء البحث الحالي بهدف الوقوف علي النمط المناسب لتقديم المراجعة الإلكترونية ببيئة الفصول المعكوسة المعدة لتتمية التحصيل. مشكلة البحث:

ومما سبق عرضـاه يمكن تحديد مشكلة البحث الحالي في: الحاجة إلى تحديد أنسب نمط من بين أنماط المراجعة الإلكترونية (فردي، ثنائي، جماعي) داخل بيئة الفصل المعكوس وذلك فيما يتعلق بتأثيرهما على التحصيل، ويعد البحث الحالي أحد Aptitude Treatment-Interaction (A. بحوث التفاعل بين الإستعداد والمعالجة

ويمكن معالجة مشكلة البحث من خلال الإجابة على السؤال التالي: 
نمط المراجعة الاكتررونية (فردي، ثنائي، جماعي) في بيئة الفصول أ. هنادي محمد أنور

مـا نمــ المراجعـة الالكترونيـة (فردي، ثنائي، جمـاعي) في بيئة الفصـول

المعكوسة وأثرها على التحصيل لدي طلاب تكنولوجيا التعليم المتعقين والسطحين؟ وتم تقسيم هذا السؤال إلى الأسئلة الفرعية التالية:

ا.ما صورة بيئة الفصل المعكوس الملائمة لاستخدام نمط المراجعة الإلكترونية (فردي الإسي

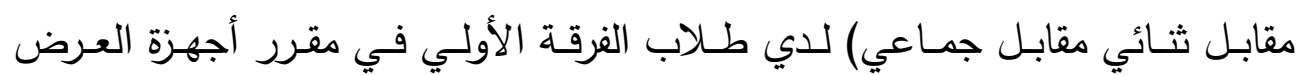
التعليمية في ضوء نموذج تصميم تعليمي مناسب؟

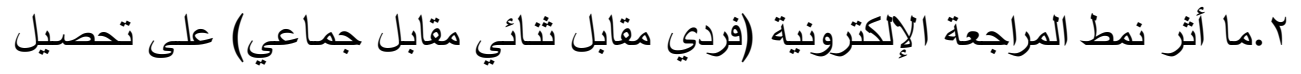
الجانب المعرفي المرتبط بمقرر أجهزة العرض التعليمية لدي طلاب تكنولوجيا التعليم

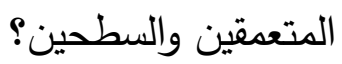
r.ما أثر الأسلوب المعرفي (المتعقين/ السطحين) عند إجراء المراجعات الإلكترونية

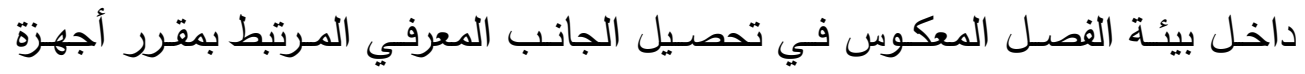
العرض التعليمية لدي طلاب تكنولوجيا التعليم المتعقين والسطحين؟

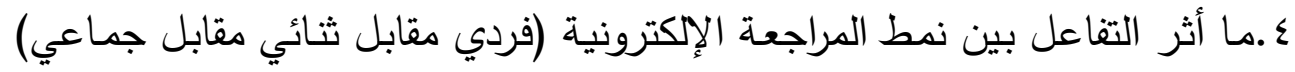

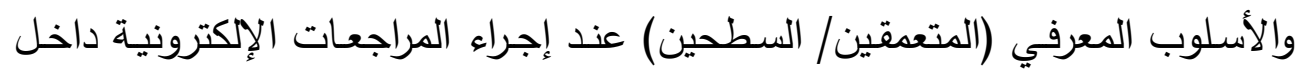

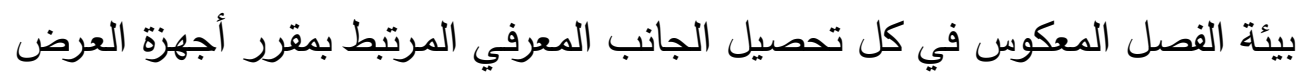
التعليمية لاي طلاب تكنولوجيا التعليم الستعمقين والسطحين؟

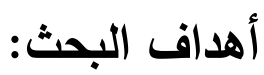

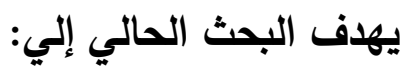
ا.تحديد صورة بيئة الفصل المعكوس الملائمة لاستخدام نمط المراجعة الإلكترونية

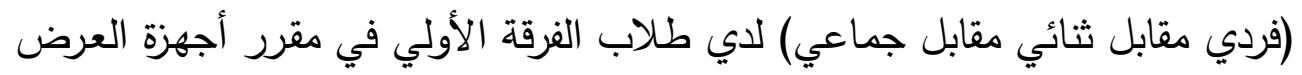
التعليمية في ضوء نموذج تصميم تعليمي مناسب.

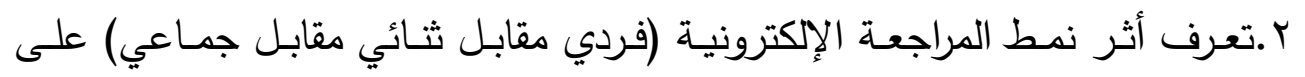

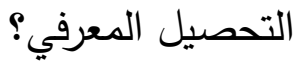




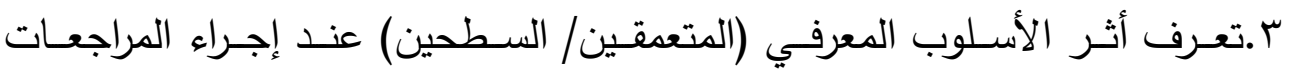
الإلكترونية داخل بيئة الفصل المعكوس في التحصيل المعرفي لدي طلاب تكنولوجيا

$$
\text { التعليק؟ }
$$

ع .تعـرف أثر التفاعـل بـين نمـط المراجعـة الإلكترونيـة (فردي مقابـل ثـائي مقابـل جماعي) والأسلوب المعرفي (المتعقين/ السطحين) عند إجراء المراجعات الإلكترونية داخل بيئة الفصل المعكوس في التحصيل المعرفي لدي طلاب تكنولوجيا التعلي؟ أهمية البحث:

من المتوقع أن يسهم البحث الحالي في المجال التربوي على النحو التالي: ا ـقد تسهم نتائج البحث في تبني المؤسسـات التعليميـة المتخصصـة أنماط وأدوات وأنواع جديدة للمراجعة الإلكترونية، سعياً للإرتقاء بمستوي نواتج التعلم المختلفة. r.قد تسـهم نتائج هذا البحث في تزويـ مصـمي ومطوري هذه البيئات التعليميـة

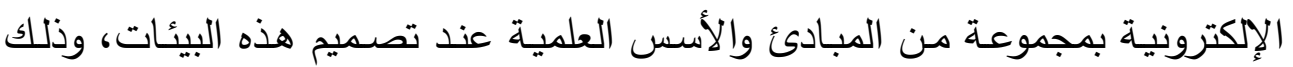
فيما يتعلق بإستخدام المراجعات الإلكترونيـة الفرديـة والثنائيـة والجماعيـة داخل بيئة الفصل المعكوس لتنمية التحصيل لدي الطلاب. r.قد تقيد نتائج هذا البحث في تزويد أعضاء هيئة التدريس ومعاونيهح بأنماط وأدوات

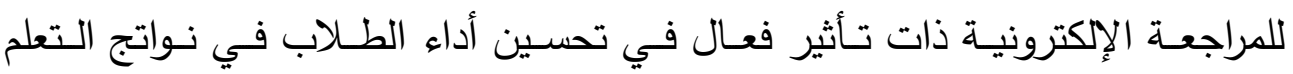
المختلفة. حدود البحث: أقتصر البحث الحالي علي: ا .حدود موضـوعية: مـن خـلال تتـاول أربعـة موضـوعات في مقرر أجهزة العرض التعليميـة الذي يقوم بدراسته الفرقـة الأولي قسم تكنولوجيا التعليم بالفصـل الدراسـي الثاني، وذلك من خلال نمط المراجعة الالكترونية (فردي مقابل ثنائي مقابل جماعي) داخل بيئة الفصول المعكوسة لطلاب تكنولوجيا التعليم. 
نمط المراجعة الاكترونية (فردي، ثنائي، جماعي) في بيئة الفصول أ. هنادي محمد أنور

r.حدود بشرية: عينة من طلاب الفرقة الأولي -قسم تكنولوجيا التعليم. r.حدود مكانية: كلية التربية النوعية -جامعة عين شمس.

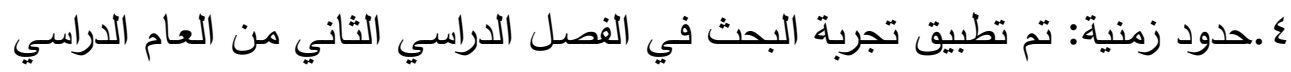
.r. IN-r.IV

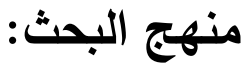

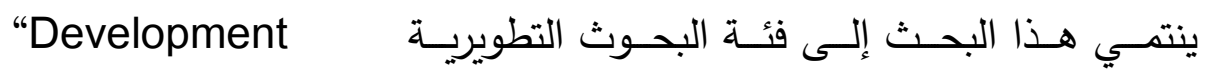
Reasearch”

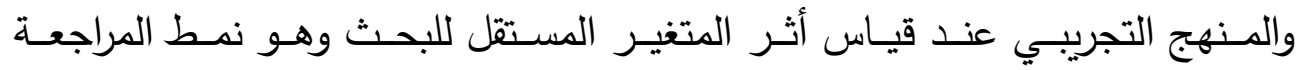
الإككترونية (فردي مقابل ثنائي مقابل جماعي) على المتغير التابع في مرحلة التقويم.

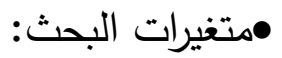

يوضح الجدول التالي متغيرات البحث محل الدراسة: جدول ( ) متغيرات البحث محل الدراسة

نمط المراجعة الإلكترونية داخل بيئة الفصول المعكوسة وله ثلاثة أنماط هما (فردي مقابل ثنائي مقابل جماعي). المستقل الأسلوب المعرفي وهو متغير تصنيفي، وله قطبين:

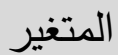

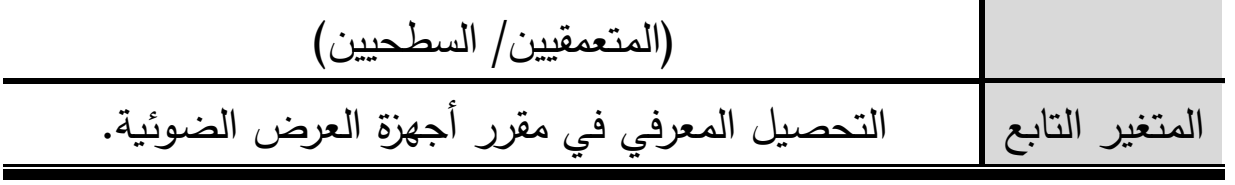

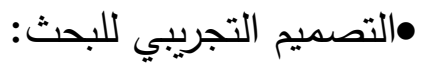
في ضـوء المتغيرين المستقلين موضـع البحث الحسالي وانماطـه، تم إستخدام

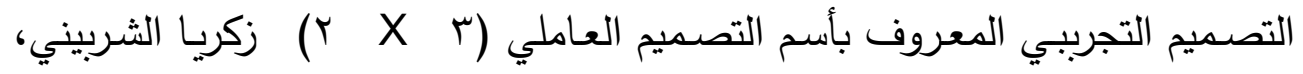
1990، ص .9\%) ويوضح الجدول التالي التصميم التجريبي للبحث الحالي: 
جدول (Y) التصميم التجريبي للبحث (التصميم العاملي ب × r)

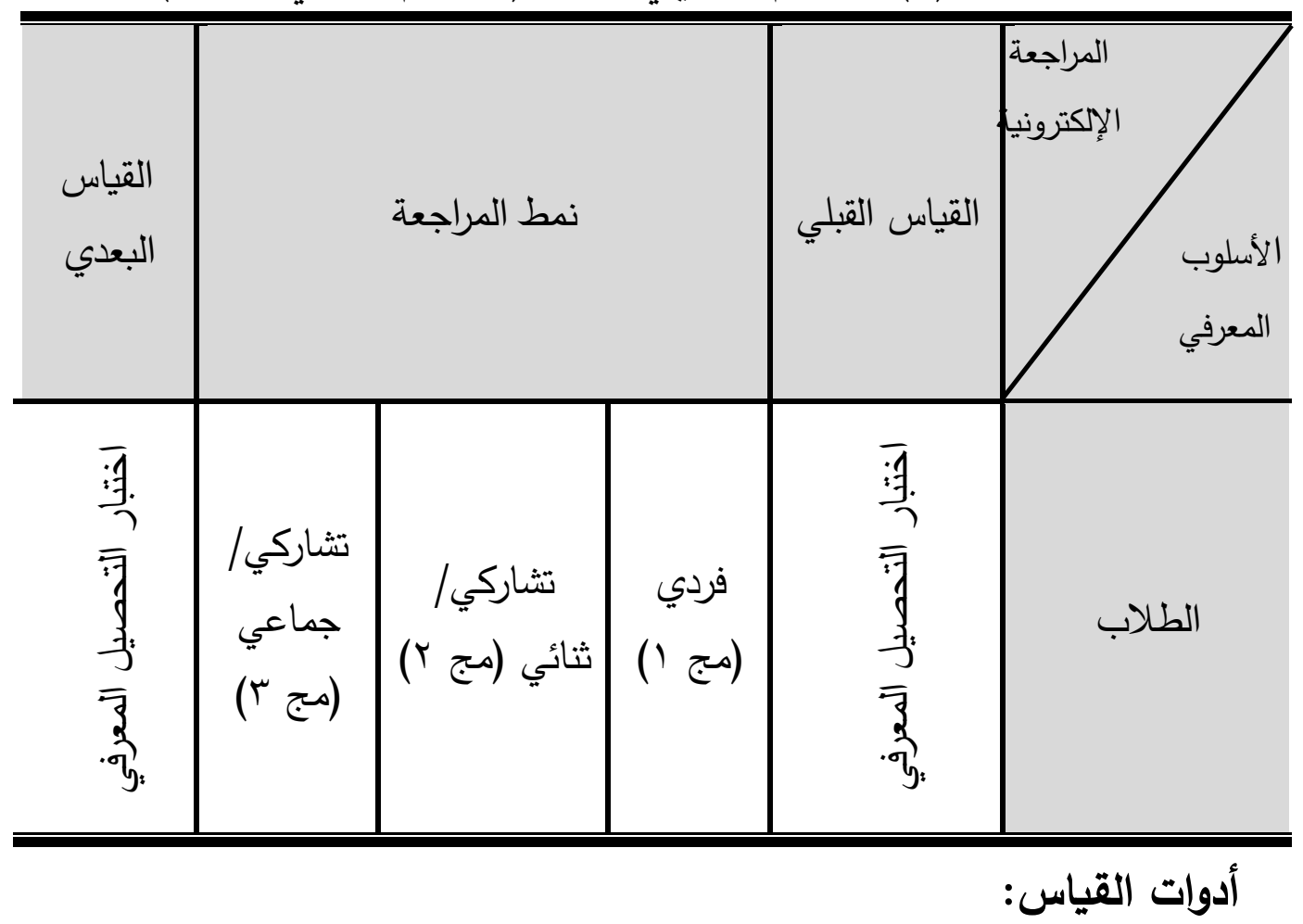

ا .اختبـار تحصسيل في مقرر أجهـزة العـرض الضـوئية لطـلاب الفرقـة الأولي بقسم تكنولوجيا التعليم (من إعداد الباحثة).

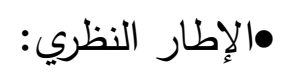

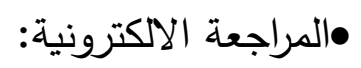
•مفهوم المراجعة الالكترونية: يصف عبد المطلب جابر وآخرين (T . r) المراجعة بأنها استراتيجيات وآليات

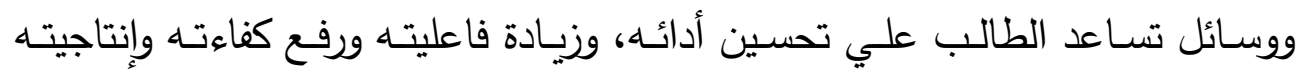
التعليمية. 
نمط المراجعة الاكترونية (فردي، ثنائي، جماعي) في بيئة الفصول أ. هنادي محمد أنور

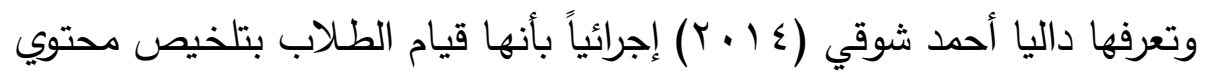

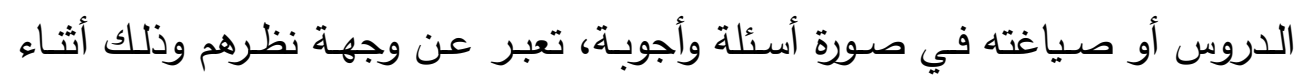

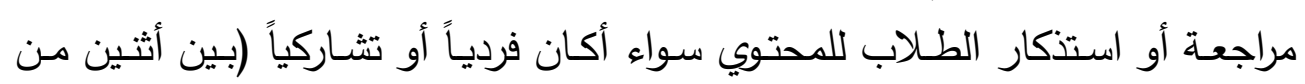

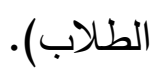

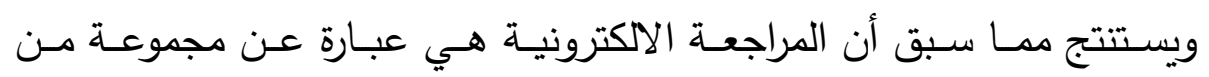

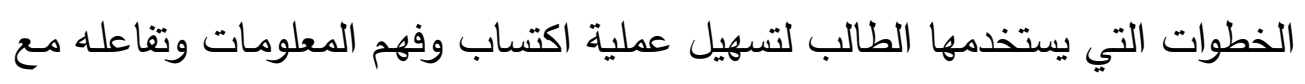

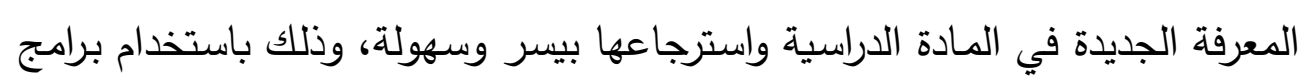
الكبيوتر وشبكات التواصل الاجتماعي ومنصـات التعلم الالكتروني المختلفة، ويتم ذلك بثكل فردي أو ثنائي أو جماعي. إستراتيجيات المراجعة الاكترونية:

يوجد العديد من استراتيجيات المراجعة والتي يذكرها كلاً من: (السيد محمد أبو الأبئ

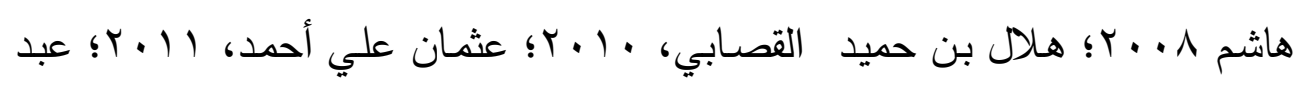

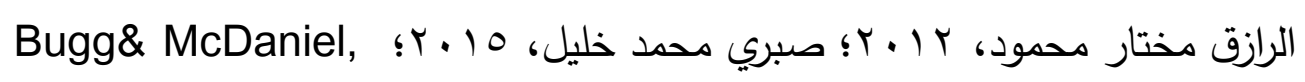

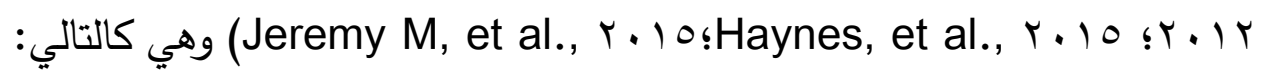

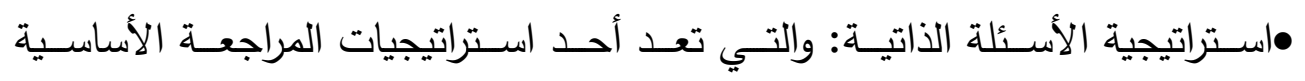

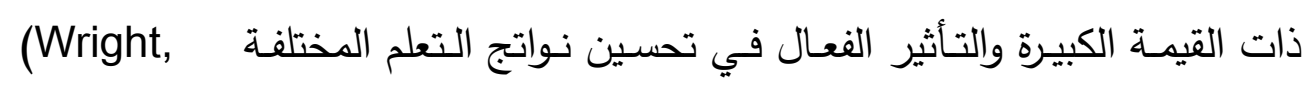
r...人)

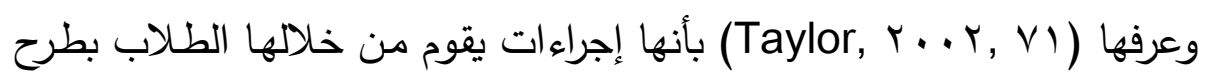

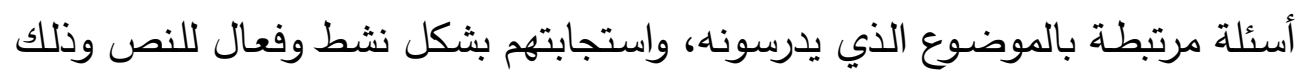

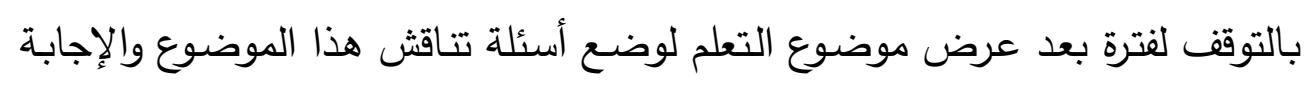
عليها مما يساعد علي تتمية الفهم والتفكير. 
خطــوات تنفيــذ اســتراتيجية الأســـلة الذاتيــة داخـل بيئــة الفصــول المعكوسة كما تم إجرائها في البحث الحالي: •تنقسم هذه الإستراتيجية إلى ثلاثة مراحل كالأتي: •المرحلة الأولي: ما قبل التعلم: وتتضمن الأتئي:

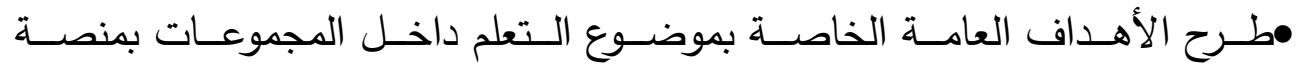

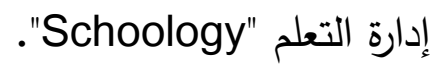

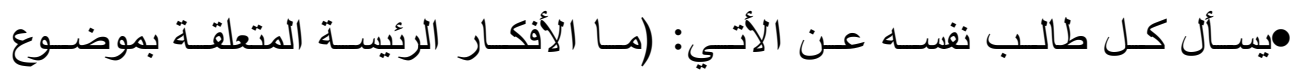

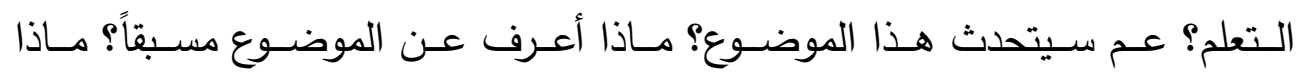

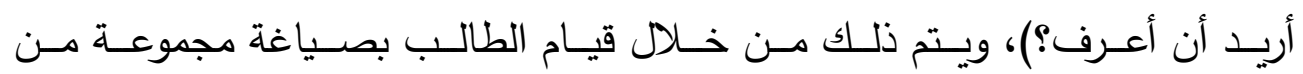
الأسئلة في تعليقات أسفل الأهداف العامة.

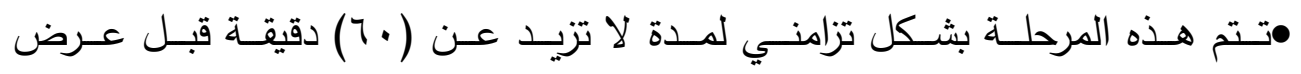
الفيديو في المرحلة التالية (أثناء التعلم). •المرحلة الثانية: أثناء التعلم: وتتضمن الأتي:

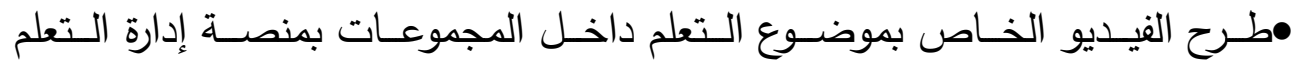
"Schoology"، وإتاحته للعرض والمشاهدة وفقاً للخطو الذاتي لكل طالب.

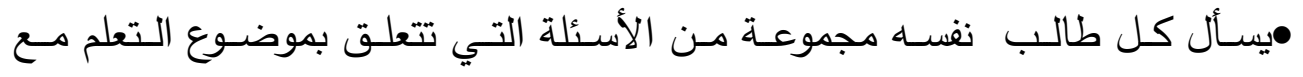

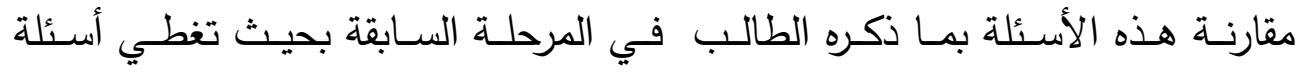

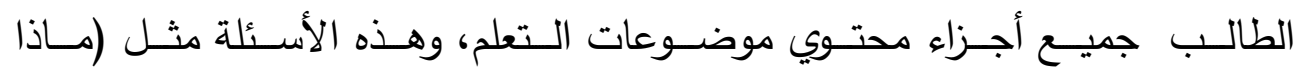

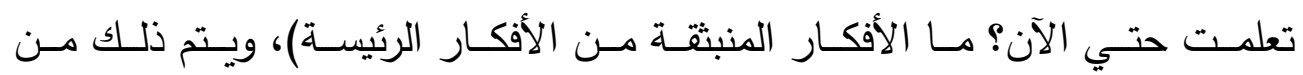
خلا قيام الطالب بصياغة مجموعة من الأسئلة في تعليقات أسفل فيديو.

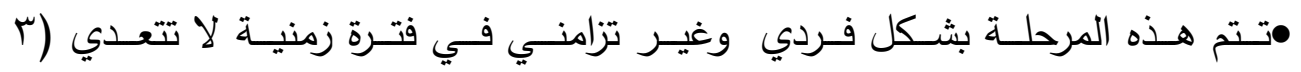
أيام) من إتاحة الفيديو للعرض والمشاهدة والتفاعل. 
نمط المراجعة الاكترونية (فردي، ثنائي، جماعي) في بيئة الفصول أ. هنادي محمد أنور

•المرحلة الثالثة: بعد التعلم وتتضمن الأتي:

تنقسم هذه المرحلة إلي شقين وهما:

•الثق الأول: تنفيذ النشاط: ويتضمن الأتي

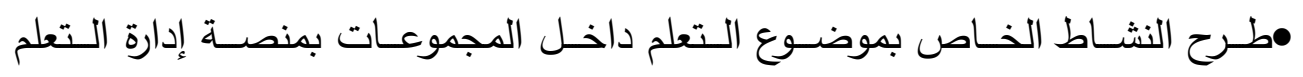

."Schoology"

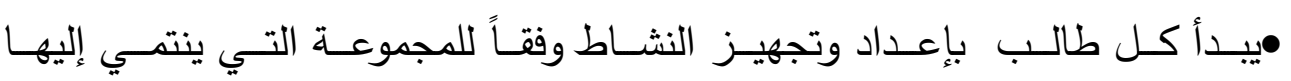
سواء كان بثكل (فردي أو ثنائي أو جماعي).

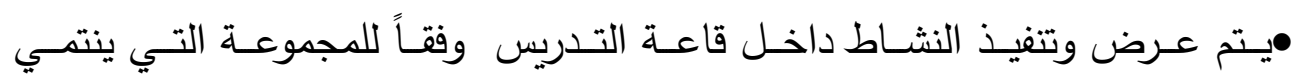

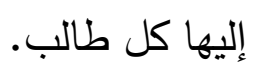
•يقوم الطلاب بعد ذلك بطرح النثاط داخل منصة إدارة التعلم"Schology". •الثق الثاني: إجراء المراجعة الإلكترونية ويتضمن الأتي:

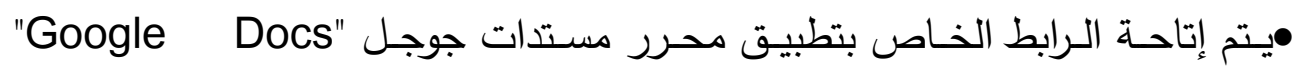

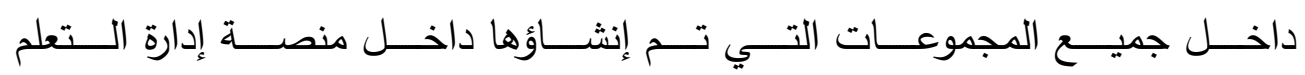
."Schoology"

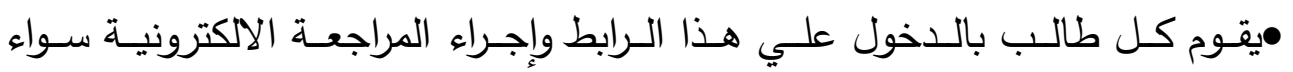

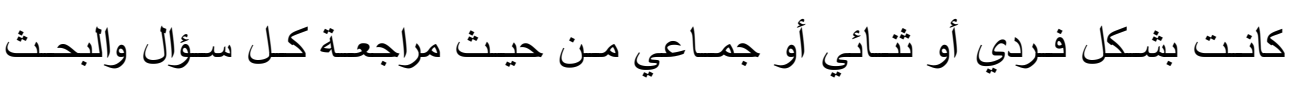

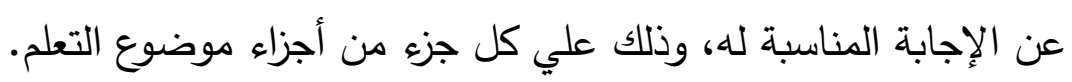

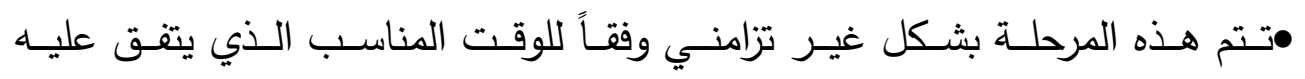
طلاب كل مجموعة مع بعضها البعض في فترة لا تتجاوز يومان. •أنماط المراجعة الآكترونية ( الفردي والثنائي والجماعي).

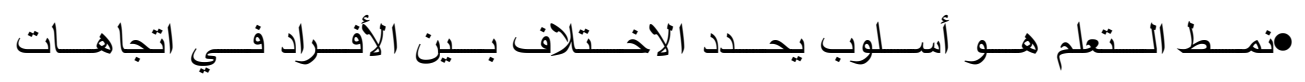

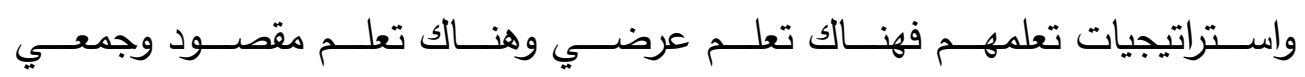

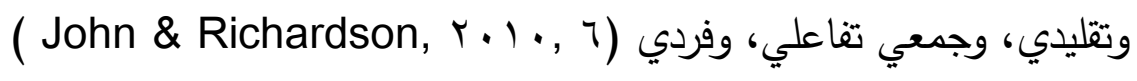




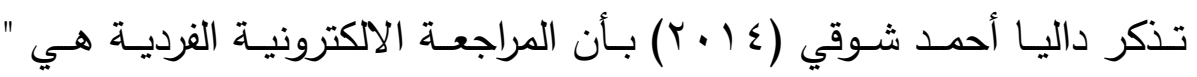

اسـتراتيجية تعليميـة تسـح لكل طالب منفرداً بمراجعـة الـدروس المتاحسة الكترونيـاً باستخدام أدوات التحكم في النص أو اضـافة التعليقات وذلك باستخدام استراتيجية التلخيص أو استراتيجية الأسئلة. •منطي المراجعة الالكترونية الثنائي والجماعي. •مفهوم المراجعات الالكترونية الثنائية والجماعية: تذكر (Leaza\& Perez, r.... r r أن المراجعة الالكترونية الجماعية هي طريقة تعلم تعتمد علي استخدام التكنولوجيا القائمة علي بيئة التعلم القائم علي الكمبيوتر؛ تهدف إلي خلق طرق جديدة للتعلم تعتمد علي مشاركة المتعلمين في التعلم من خلال المصادر التكنولوجية المختلفة. وتعد استراتيجية المراجعـة الالكترونيـة في ثنائيات إحدي إستراتيجيات التعلم الجماعي النشط، والتي تساعد علي تفاعل أثنان من المتعلمين مـع بعضهم البعض التص وتحقيق التعلم الفعال، وهي شكل من أشكال التعلم الجماعي النشط الذي يعتمد علي (Mckeachie, تبادل الأفكار في صورة أسئلة وإجابات بين أثنين من المتعلمين فقط وهن $.199 \varepsilon$ )

•خطوات ومراحل نمط تفاعل الطلاب داخل المراجعة الالكترونية الثنائية: وبـالاطلاع علي أشكال التفاعلات التي تحدث بين ثنائي/جمـاعي المراجعـة قامت الباحثة بتحديد أشكال التفاعلات التي تتم بين الطلاب أثناء التشارك لانجاز مهام المراجعة الالكترونية داخل بيئة الفصول المعكوسة والتي تمثلت في يلي: ا .النقاش والحوار بين ثنائي/جماعي المراجعـة من أجل فهم الموضـوعات الدراسية المطلوب مراجعتها. 
نمط المراجعة الاكترونية (فردي، ثنائي، جماعي) في بيئة الفصول أ. هنادي محمد أنور

r.تفـاعلات الطـلاب واستقبال المعلومـات والدعـارف المرتبطــة بكل موضـوع مـن موضوعات الدراسة والتي عددها (؛) موضوعات، وهذه التفاعلات تتمثل في قدرة الطلاب علي الشرح والتوضيح والتبرير .

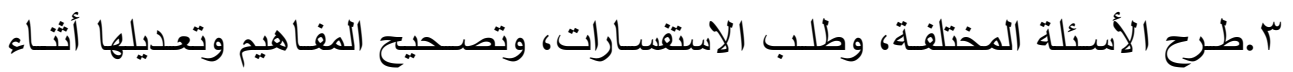
التفاعل الجماعي بين ثنائي/جماعي المراجعة الالكترونية.

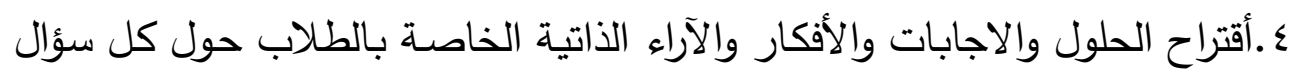
من الأسئلة التي وضعوها في ضول والاه ما يمتلكون من معارف ومعلومات.

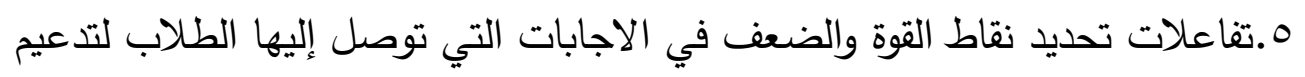
نقاط القوة، ومراجعة وتعديل نقاط الضعف. 7.الاعتماد المتبادل بين ثنائي/جماعي المراجعة مع تدعيم المسئولية الفردية الايجابية أثناء التشارك في انجاز مهمة المراجعة الآكترونية المحددة.

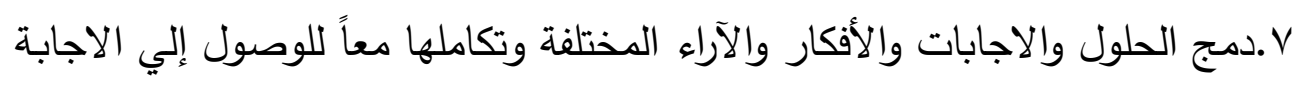

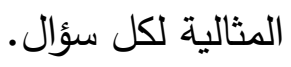
1.طلب وتقديم الدعم والمساعدة بين ثنائي/جماعي المراجعة الاككترونية.

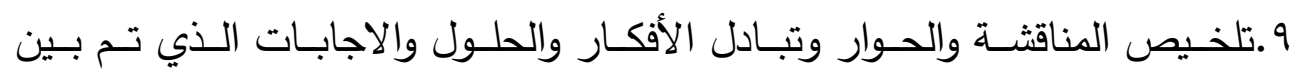
ثنائي/جماعي للوصول إلي القرار النهائي.

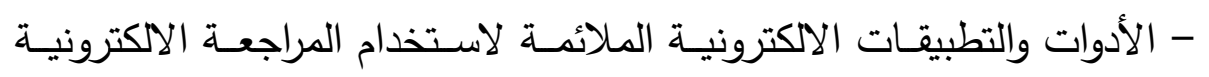
بأنماطها (الفردي، الثنائي، الجماعي) داخل بيئة الفصول المعكوسة. • • بنصة إدارة التعلم "Schoology":

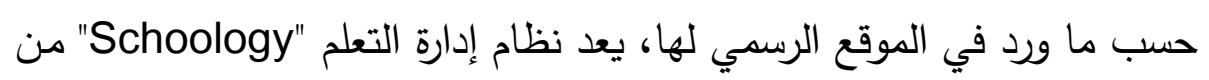

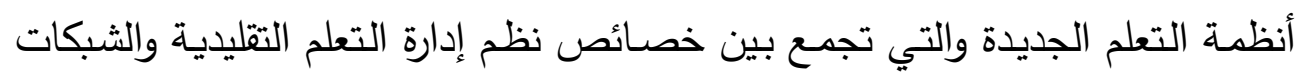

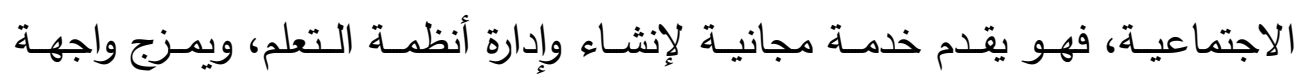

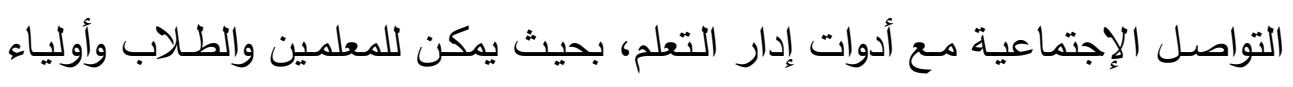


الأمور والإداريين من الاتصال والتعاون في الأمور التعليمية. ويمكن تعريفها أيضـاً بأنها : منصـة تعليمية تستخدم نظام إدارة التعلم LMS وتتميز بواجهة تفاعلية سهلة الاستخدام شبيهة بمواقع التواصل الاجتماعي وتسهل التواصل والتفاعل والتشارك بين المعلم والطلاب وأولياء الأمور لتحقيق الأهداف التعليمية المطلوبة. مميزات نظام إدارة التعلم "Schoology": •تسـاعد المعلم مـن إعداد وتجهيز تكليفات الطـلاب في اوقات معينـة ومحددة ويتم إبلاغ الطلاب بذلك. •تساعد المعلم والطلاب علي تبادل إرسال الرسائل الخاصة فيما بينهم من خلال أداة

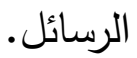

•تضم الثاشة جميع المعلومات الكاديمية وعملية استخدامها سهلة. •تساعد المعلم علي عمل استطلاع رأي ومشاركته من خلال الفيس بوك وتويتر . •تساعد المعلم علي إنشاء العديد من المقررات الدراسية، والمجموعات داخل المنصـة التعليمية "Schoology". •المجموعـات والمقررات داخل المنصــة يكـون لهـا أكواد خاصـة، يستطيع الطالب الحصول علي الكود الخاص بمجموعته أو بالمقرر. •الدراسي من المعلم. - مان.

•تساعد المعلم علي تحفيز الطلاب من خلال أيقونات التحفيز . •تساعد المعلم والطلاب علي التفاعل والتشارك في المناقثات التي تتم بينهم. •سهولة التواصل بين المعلم والطلاب. •تساعد أولياء الأمور من معرفة المستوي التحصيلي لأبنائهم.

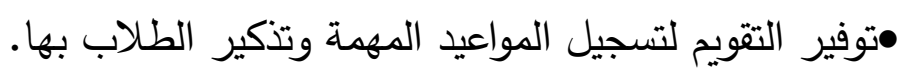


نمط المراجعة الاكتررونية (فردي، ثنائي، جماعي) في بيئة الفصول أ. هنادي محمد أنور

تطبيق محرر مستتدات جوجل "Google Docs" : يعد أحد التطبيقات التثاركية المهـة والفعالة في إجراء معالجة النصوص علي الانترنت، حيث يساعد إلي إنشاء الملفات وتنيسقها بشكل مناسب، والتشارك فيها في الوقت المطلوب. -ومن مميزات تطبيق محرر مستندات جوجل "Google Docs"

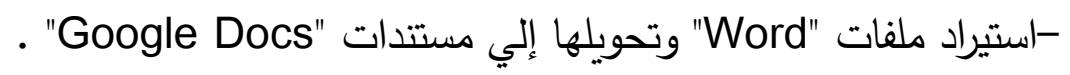

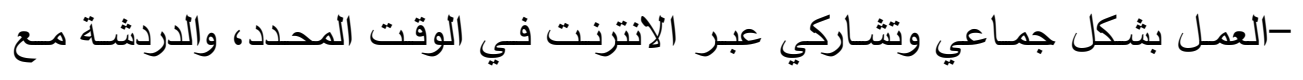
الزملاء.

- تعديل وتنسيق الملفات عن طريق إستخدام الهوامش، والمسافات بين الأسطر، وأنواع الخطوط والألوان والأشكال التخطيطية المختلفة......

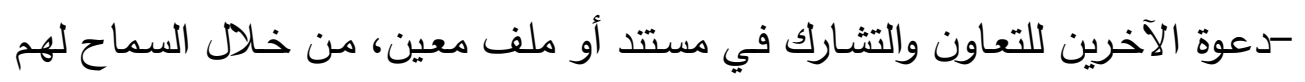
بالتعديل أو التعليق فقط. Deep and Surface أسلوب التعلم (العيق مقابـل السطحي) Learning Style مفهوم أسلوب التعلم العميق والسطحي وخصائصه:

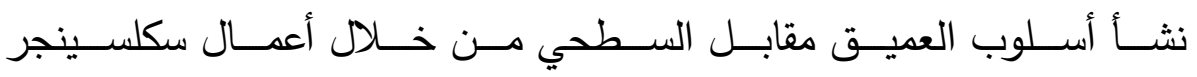
(Schlesinger, 190)، ووصفه بأنه المحافظة علي السلوك الضيق، ويعرف بأنه

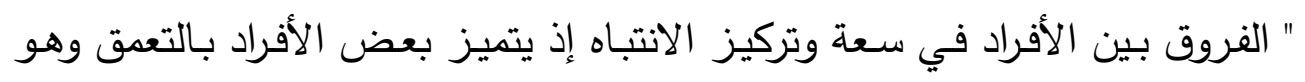

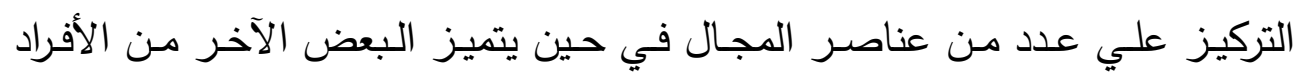

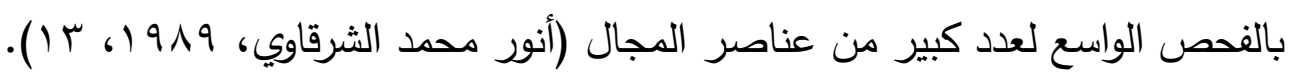

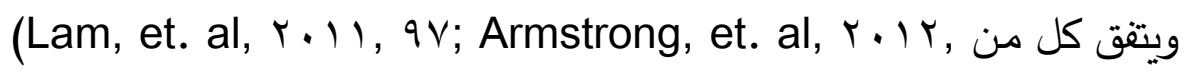

(9) § ؛ علي أن أسلوب التعلم يعرف بأنه "اختلاف الطلاب في التركيز علي المواقف

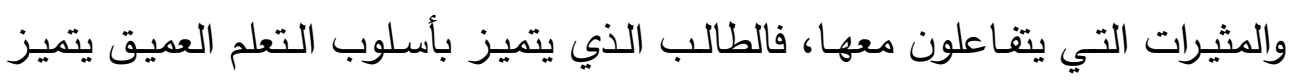

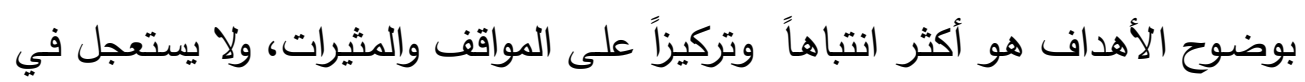


معالجـة المعلومـات وإصـدار الأحكام واتخـاذ القرارات بثـأنها، بينمـا نجد أن الطالب الذي يتميز بأسلوب التعدم السطحي هو سريع في فحص الموقف ووضع الفروض

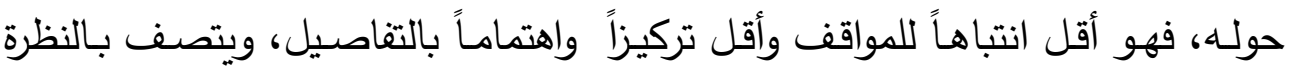
السطحية وضيق الانتباه من حيث مدته وعدد المثيرات التي يتم متابعتها مما يجعل ردود أفعاله متسرعة".

وتستخلص الباحثة خصـائص الطـلاب ذوي أسلوب التعلم (التعقق/السطحي) من خلال هذا البحث وهي كالأتي: الطالب ذوي أسلوب التعلم السطحي يتسم بالتركيز

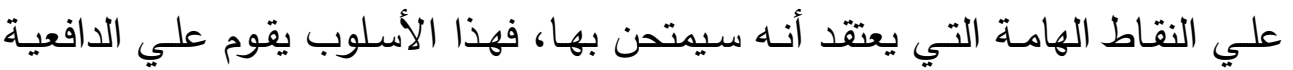
الخارجيـة، والخوف من الفشل، وأصـحابه يرون أن التعلم هو طريقهم نحو غايات أخري أهمها الحصول علي وظيفة، وهدفهم الأساسي هو متطلبات المحتوي الدراسي مـن خـلال حفظ وتـكر واسترجاع المحتوي الدراسـي الذي يعتقدون أنـه سيأتي في الامتحان، ويحفظون عن ظهر قلب معلومات بسيطة من أجل الامتحان، في الوقت الذي يتطلب فيـه قيامهم بالمراجعـة الالكترونيـة، تحديد أهداف التعلم بثكل دقيق، والعمل علي تقييم مدي فاعلية استراتيجية المراجعة الاككترونية أثناء التعلم من خلال تحديد مقدار فهم المعلومـات واستيعابها ومدي السير باتجاه تحقيق الأهداف، أمـا ماهـ الطـلاب ذوي أسـلوب التعلم العميق يهتمـون بالمـادة الدراسـية، وفهمها، واستيعابها، ويدركون أهميتها المهنية، ومن أجل ذلك يلجؤون إلي البحث عن المعني من خلال ربط القديم بالجديد، وربط الأفكار النظريـة بالحياة العملية، وتحديد الأفكار الرئيسية،

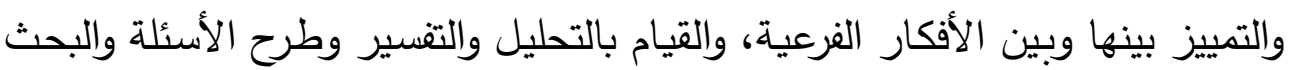
عن إجاباتها والتلخيص من أجل بناء المحتوي الدراسي بشكل أوضح وأشمل. وقد أشارت عديد من الدراسات إلي الفروق بين التعلم العميق والسطحي، ومنها

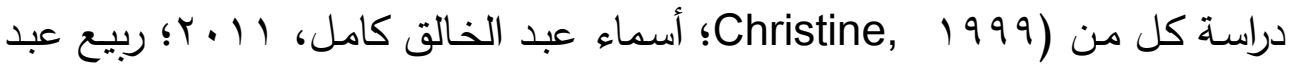

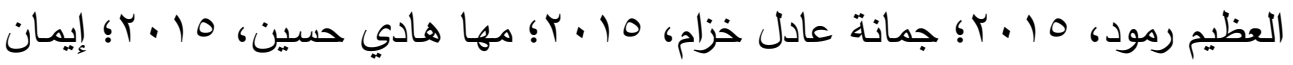


نمط المراجعة الاكترونية (فردي، ثنائي، جماعي) في بيئة الفصول أ. هنادي محمد أنور

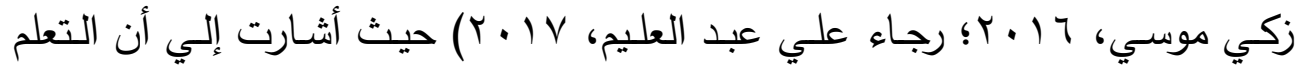

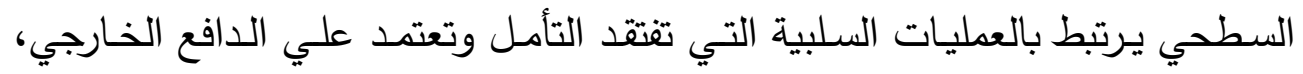

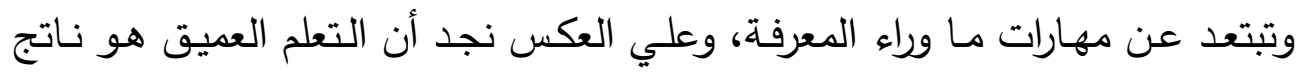

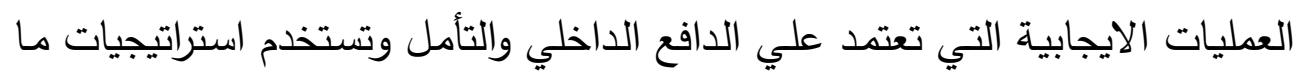

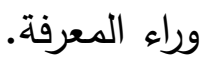

بناء بيئة المراجعة الاكترونية داخل الفصول المعكوسة:

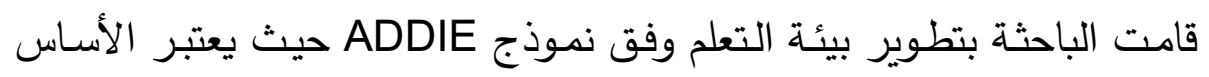

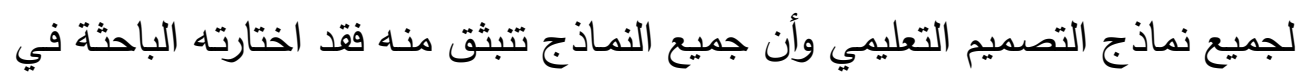

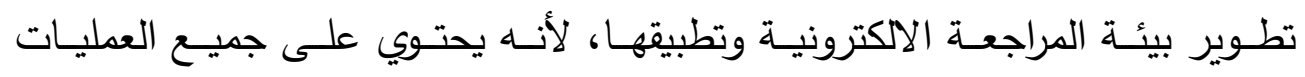

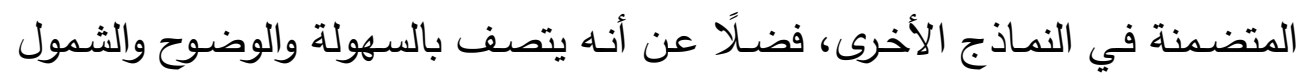

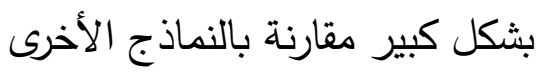

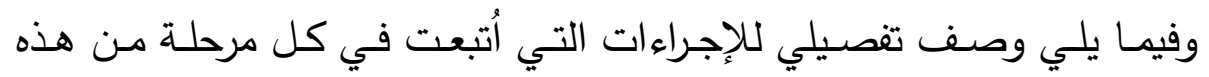

\section{مرحلة التحليل:}

شملت هذه المرحلة الإجراءات التالية:

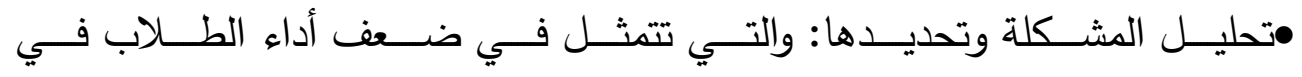

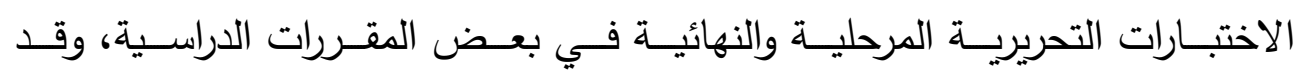

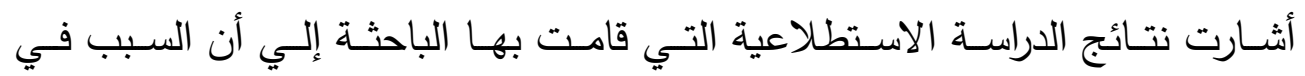

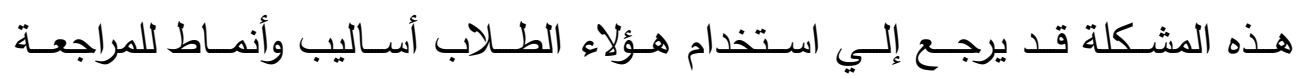

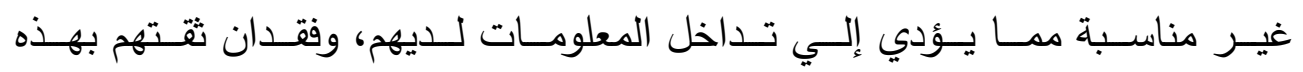

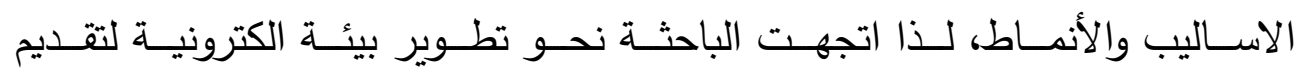
بعض الدروس الخاصة بمقرر "أجهزة العروض الضوئية" .

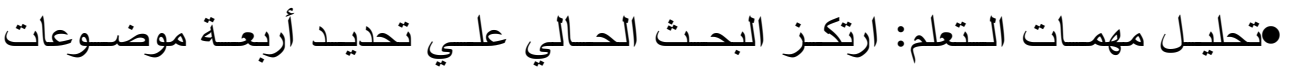


كمحتـوي رقمـي لبيئـة المراجعـة الالكترونيـة، وفـي ضـوه اطـلاع الباحثـة علـى

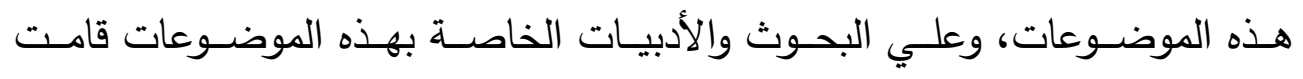
بتحديد أربعة مهمات رئيسة.

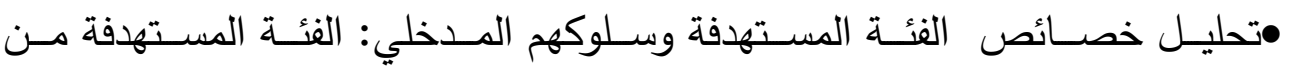

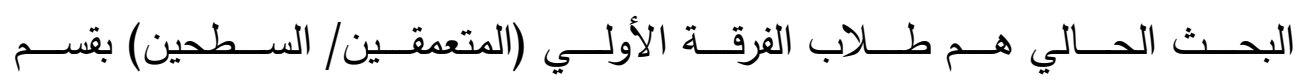
تكنولوجيـا التعلـيم -كليـة التربيـة النوعيـة-جامعـة عـين شــس الـذين يدرسـون

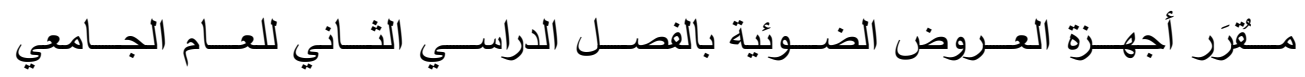

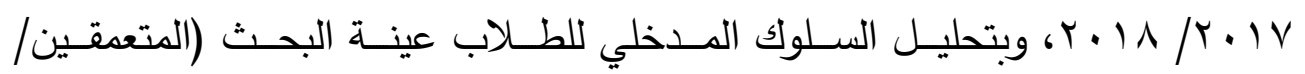

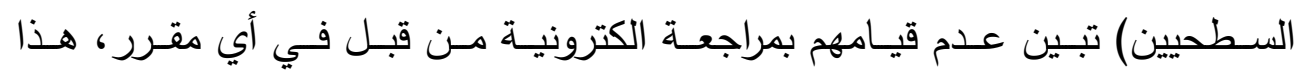
فضـلاً عـن ظهـور رغبـتهم الكبيـرة في إجـراء المراجعـات بطريقـة الكترونيـة خـلال البيئة الالكترونية المقترحة. •تحليـلـ المــوارد والقيـود فـي بيئـة الـتعلم: نظــراً لأن الـتعلم يـتم بشــل إلكترونـي

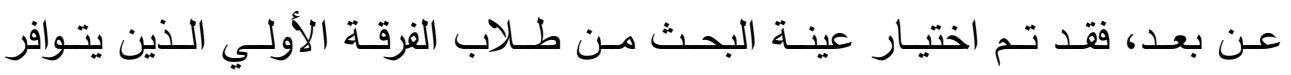

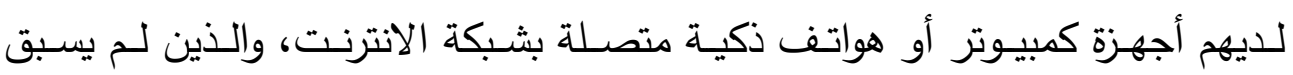

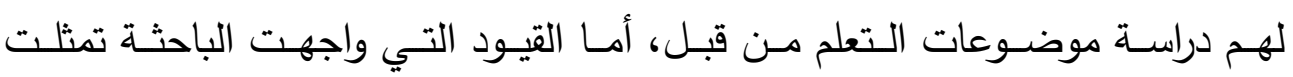
في : في

•أن الطلاب عينة البحث غير متوفر لديهم مهارات عمل حساب على نظام إدارة التعلم "Schoology" وأيضاً مهارات عمل حساب على تطبيق محرر مستتدات جوجل دوكس "Docs Google" والذي سوف يتم من خلاله إجراء المراجعات الالكترونية للدروس الأربعة.

\section{1-r مرحلة التصميم: وتتضمن هذه المرحلة الخطوات التالية:}

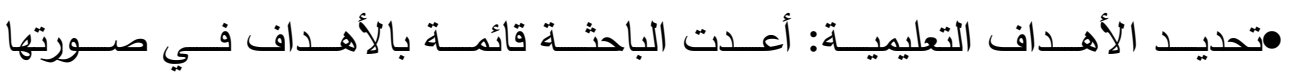

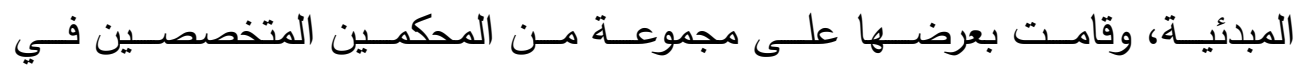


نمط المراجعة الاكترونية (فردي، ثنائي، جماعي) في بيئة الفصول أ. هنادي محمد أنور

مجـال منـاهج وطـرق وتكنولوجيـا التعليم وذلك بهـف استطلاع رأيهم في مدي

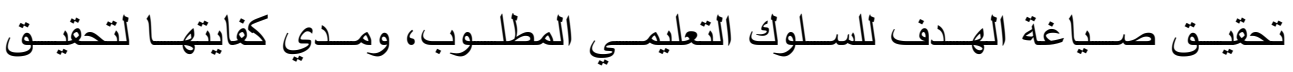

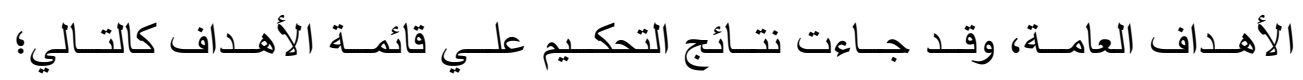

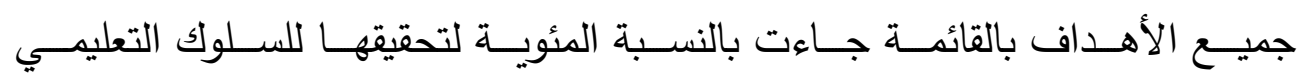

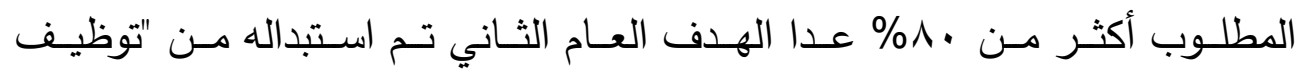

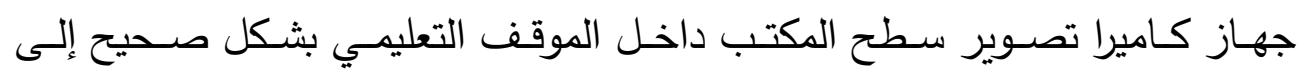

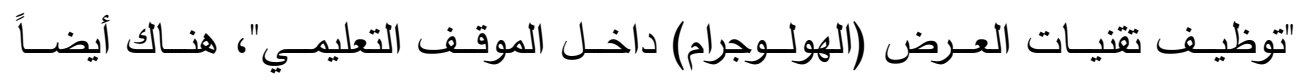

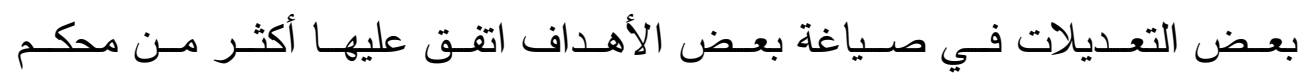

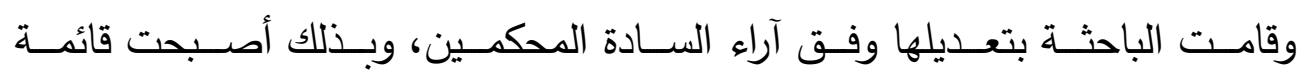

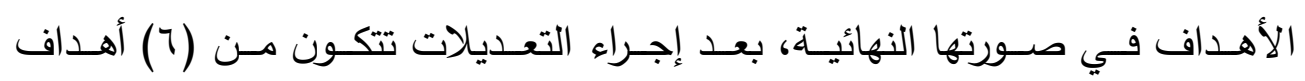

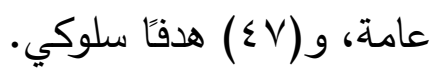

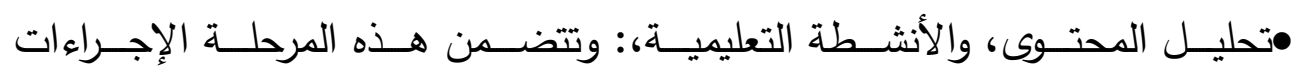

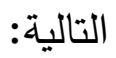
•تحليـل المحتـوى، والأنثـطة التعليميـة: أعـدت الباحثـة الدحتـوى التعليهـي فـي

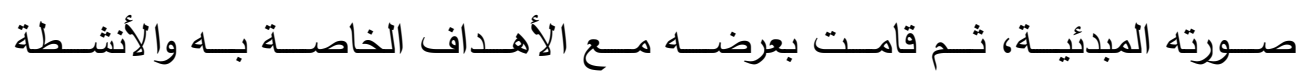

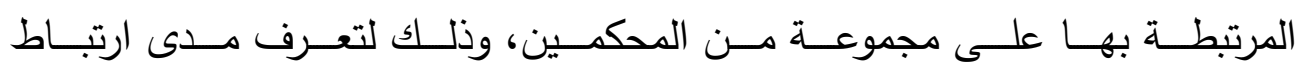

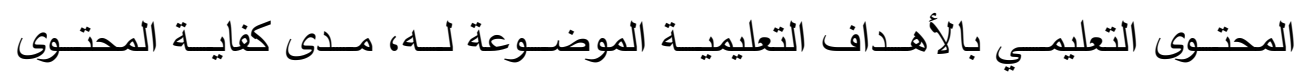

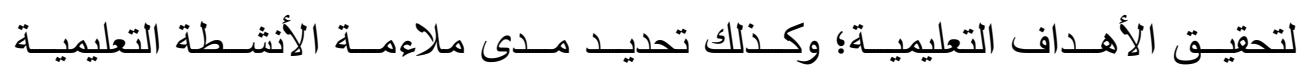

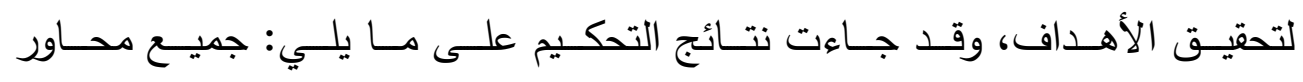

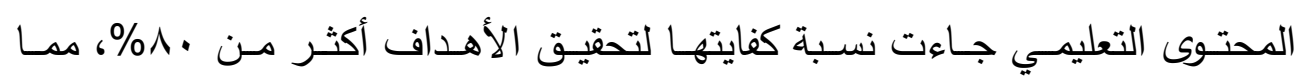

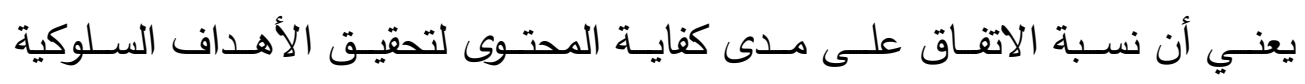

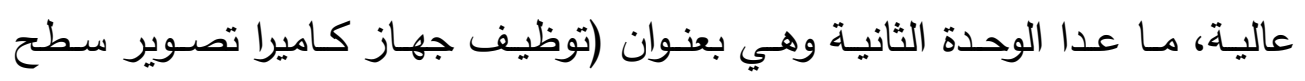

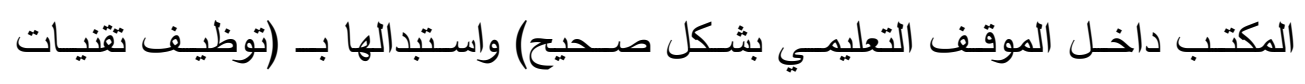


العـرض " الهولـوجرام" داخـل الموقـف التعليمسي)، ثـم تـم إعـداد المحتـوى التعليمسي في صورته النهائية تمهيدًا للاستعانة به عند بناء سيناريو بيئة التعلم.

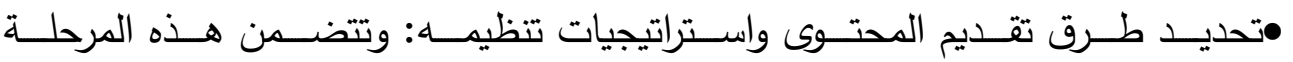
الإجراءات التالية:

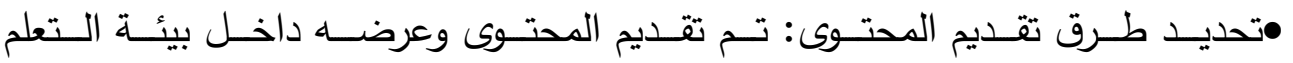
الإلكترونيـة مـن خـلال عـرض المعلومـات اللفظيـة مـن خـلال النصـوص المكتوبـة، مصــحوبة بــالتعليق الصـــتي والرســوم التوضـــيحية والرســوم المتحركـــة والصـــورة

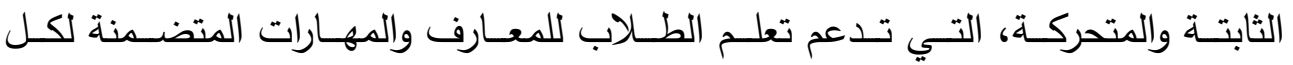

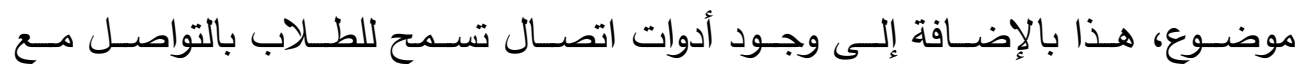

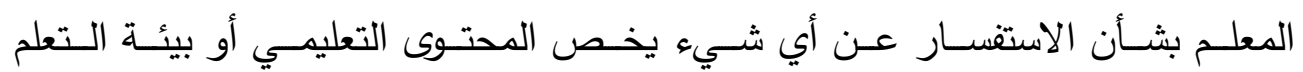
بوجٍٍ عام.

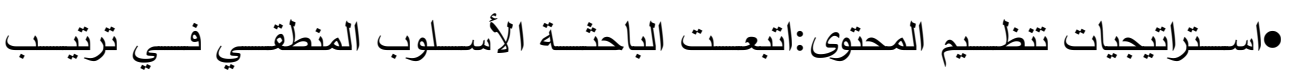

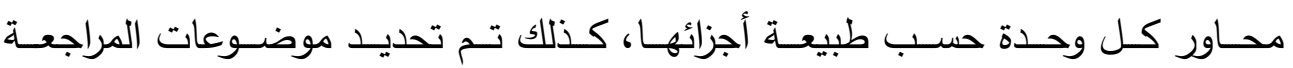

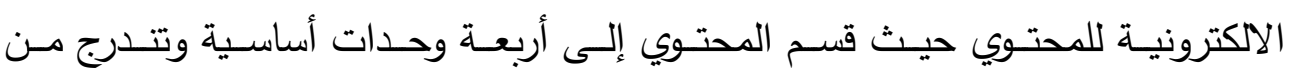
كل وحدة مجموعة من الدروس. •تصـميم أنمـاط التعليم والتعلم: يعـد نمـط التعلم أحـد متغيـرات البحثث الحسالي لـذلك

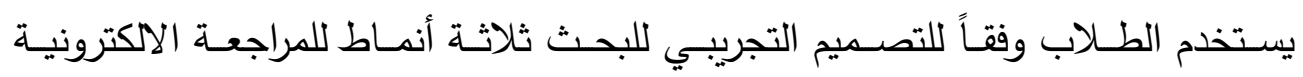
وهما: النمط الفردي، والنمط الثنائي، والنمط الجماعى.

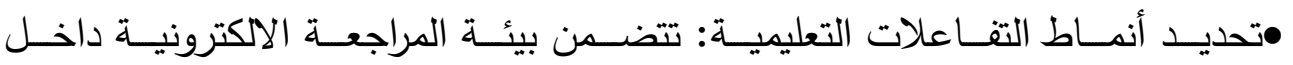
الفصول المعكوسة جميع أنواع التفاعل مع المعلم والزملاء والمحتوي.

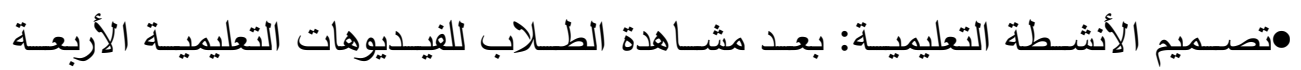
داخـل نظــام إدارة الـتعلم "Schoology" يــتم تتفيـذ النشــاط الخــاص بكـل فيـديو

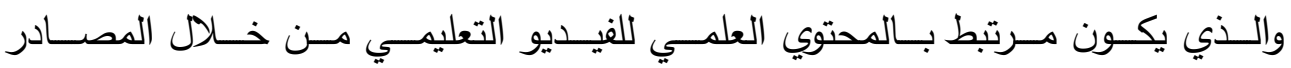
التعليمية المختلفة. 
نمط المراجعة الاكترونية (فردي، ثنائي، جماعي) في بيئة الفصول أ. هنادي محمد أنور

مرحلة التطوير: وتثمل هذه المرحلة الخطوات التالية:

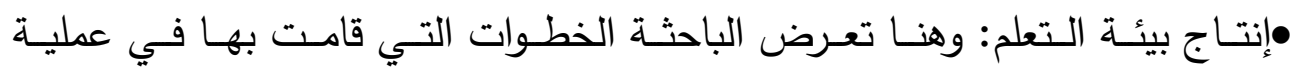
برمجـة بيئـة الـتعلم الإلكترونيـة ومتطلبـات عمليـة البرمجــة وإنتـاج مكونــات بيئسة

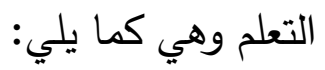

•اختيـار نظم التـأليف والإنتاج: رأت الباحثـة أن محتوي بيئـة التـعلم الإككترونيـة

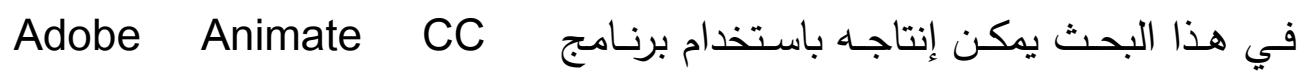

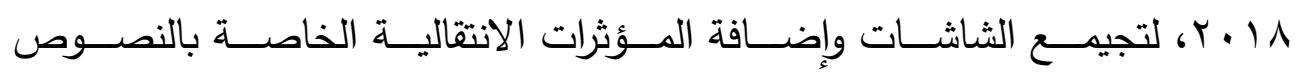
والصور والاطارات داخل الفيديو التعليمي.

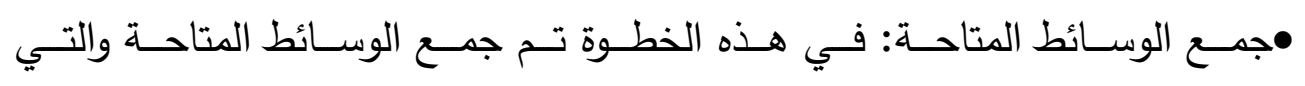
اشتملت عليها بيئة التعلم الإلكترونية وهي كما يلي:

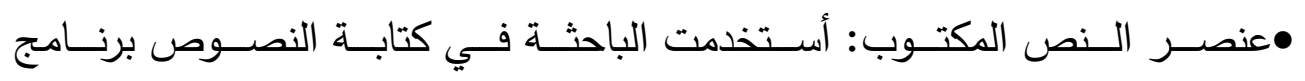

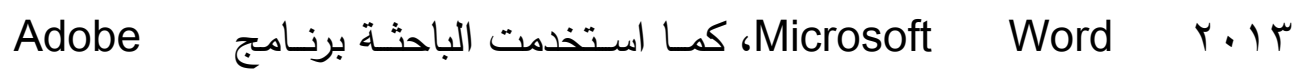
Photoshop CST

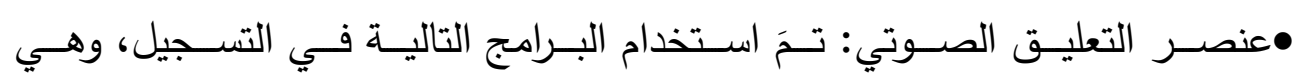
.Sound Mixer ،Adobe audition CC r.1^،Gold Wave

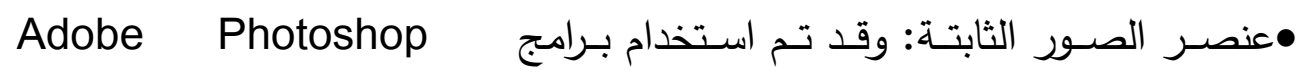
Adobe Illustrator CS7، CST بإمكانات متتوعة في معالجة الصور • عمليات التقويم البنائي لبيئة التعلم: •بعـد الانتهاء مـن إعداد بيئـة التـعلم ككل تـم ضـبطها والتحقق مـن صـلاحيتها

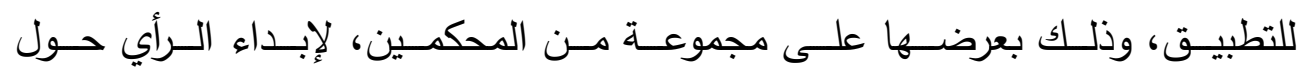

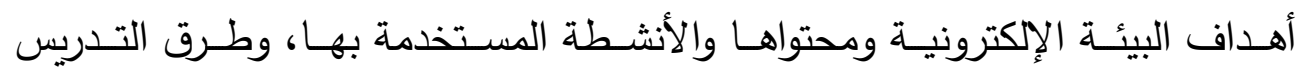

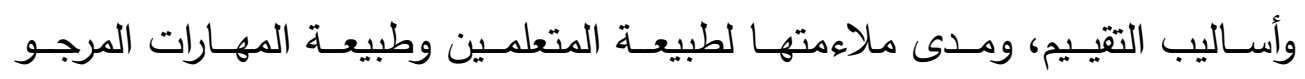




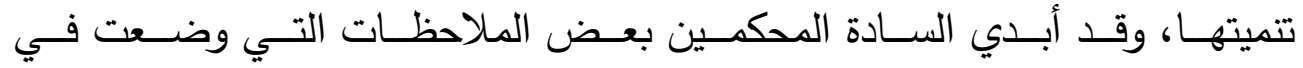

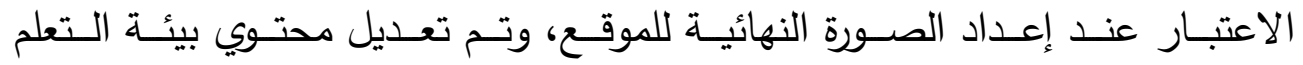
الإلكترونية حتى أصبحت في صورتها النهائية.

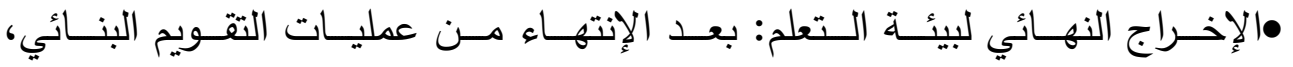

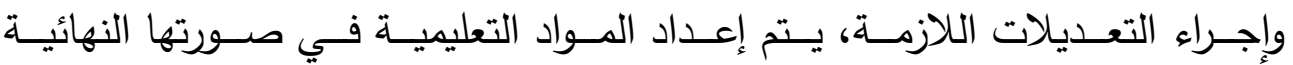
وتجهيزها للعرض على الطلاب.

مرحلة التنفيذ: تضمنت هذه المرحلة الإجراءات التالية: •النشـر : حيـث قامـت الباحثـة برفـع الفيـديوهات التعليميـة علـى نظــام إدارة الـتعلم

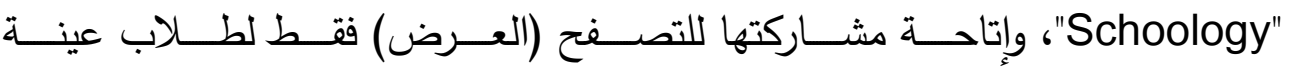
البحث.

مرحلة التقويم: تضمنت هذه المرحلة الإجراءات التالية:

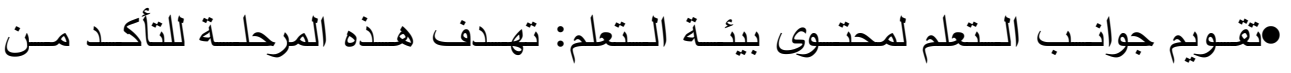
صــلاحية بيـــة الـتعلم الالكترونيـة، التـي تــم إنتاجهــا للتطبيـق، وإجـراء التجربــة

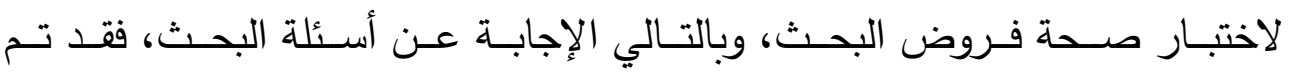

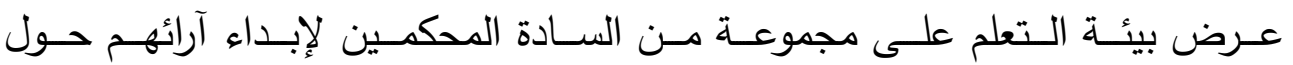
صلاحية استخدام بيئة التعلم الاكتروني لتحقيق الهدف من البحث بناء أدوات البحث: تتمثل أدوات القياس بهذا البحث الحالي في: •أسلوب التعلم (إعداد عبد الحسين رزوقي الجبوري، زينب شنان رهيف، • ( • ب). •اختبار تحصيلي مرتبط بالجوانب المعرفية لمقرر أجهزة العرض الضوئية (من إعداد الباحثة).

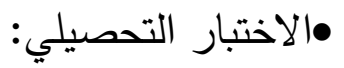
•تحديــــ الهـدف مــن الاختبــار التحصــيلي: أعـدت الباحثــة اختبــارًا تحصــيليًا 
نمط المراجعة الاكتررونية (فردي، ثنائي، جماعي) في بيئة الفصول أ. هنادي محمد أنور

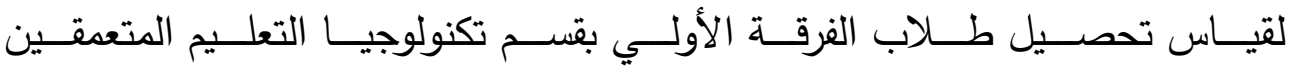

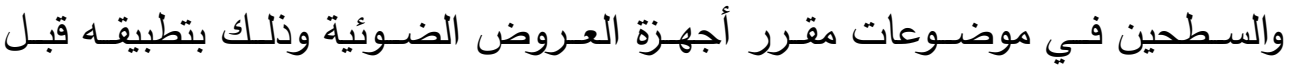
التعلم من بيئة التعلم الإلكترونية وبعده.

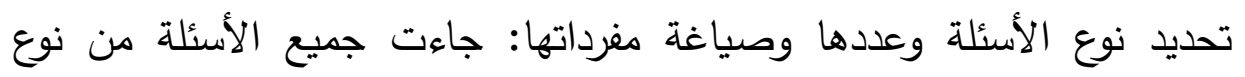

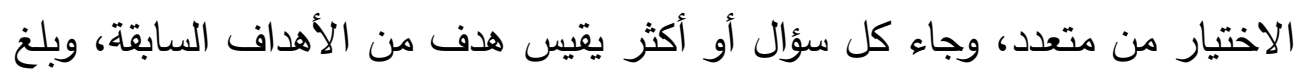
عدد الأسئلة . ا سؤالاً في صورته الأولية.

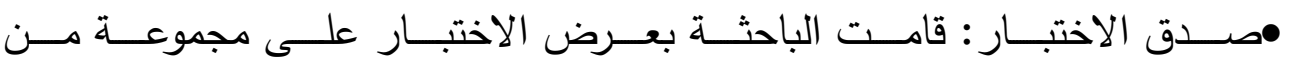

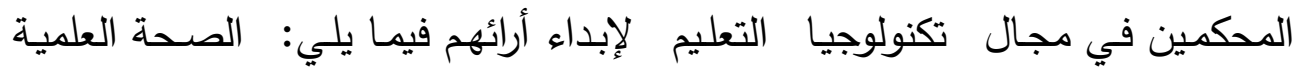

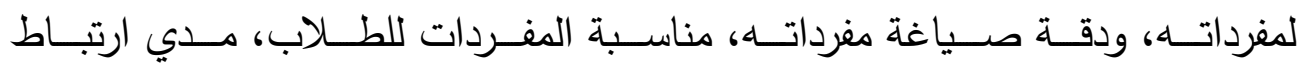

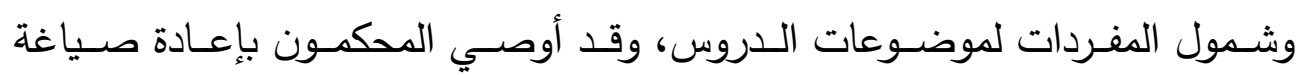

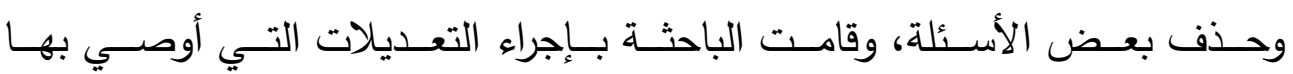
المحكمون، وأصبح الاختبار في صورته النهائية (• ون سؤالاً.

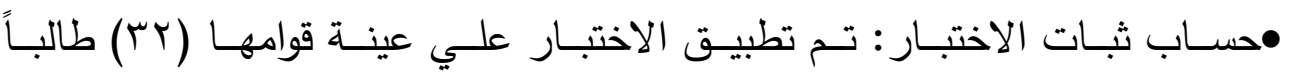

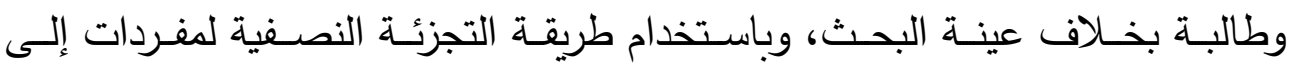

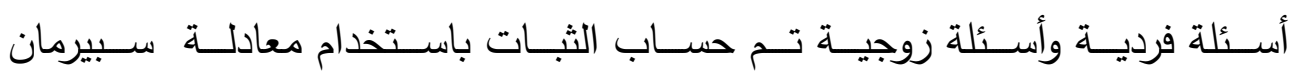

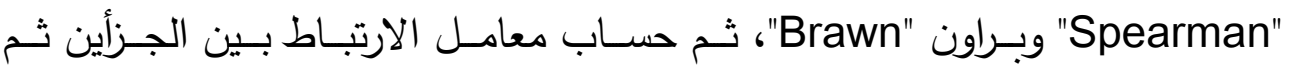

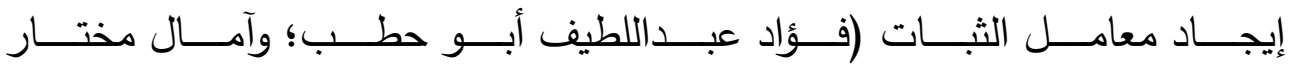

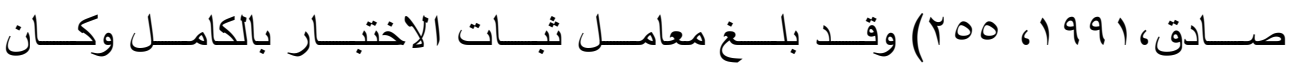
$\cdot(\cdot, 90)$ •حسـاب معامـل السـهولة المصـحح مـن أثر التخمـين بكـل مفـردة مـن مفـردات

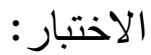

قد وقعت معاملات السهولة المصححة من أثر التخمين لمفردات الاختبار في

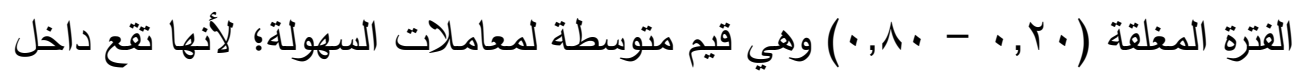




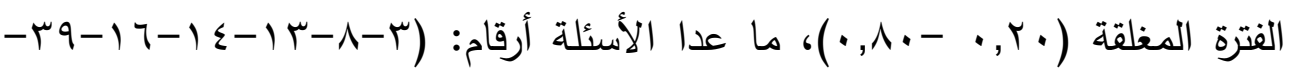

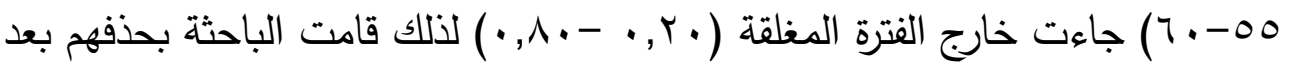
التأكد من عدم تأثيرهم على الأهداف ووجود أسئلة أخرى تغطي جميع أهداف محتوى بيئة التعلم الإلكترونية. • حسـاب معامـل سـهولة الاختبـار ككل: قامـت الباحثة بحسـاب معامـل سـهولة

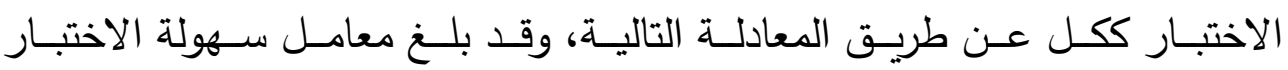
ككل (-01, (•) •حسـاب معامـل التمييـز لكـل مفـردة مـن مفـردات الاختبـار : يتضــح مـن النتـائج التـي تــم التوصـل إليهـا أن معـاملات تميــز مفـردات الاختبــار ذات قـوة تمييـز

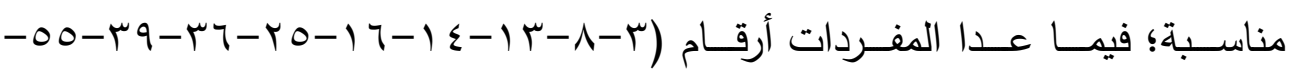

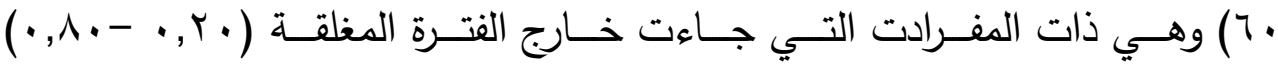
والتي قامت الباحثة بحذفها عند حساب معامل السهولة والصعوبة.

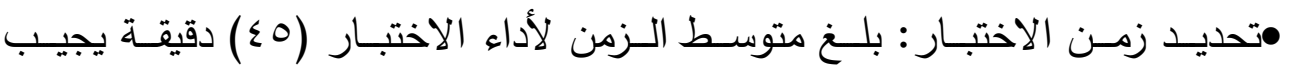
فيها الطالب عن (.0) سؤال ملحق (10).

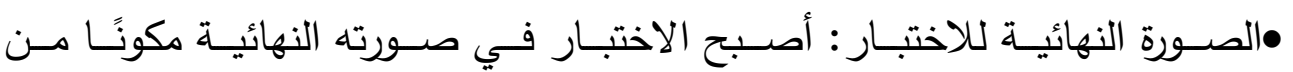

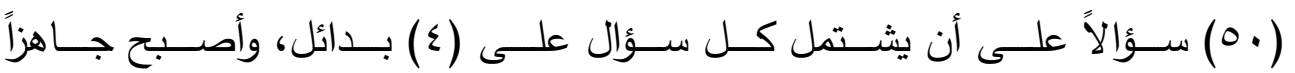
للإستخدام في تجربة البحث. ا .التجربــة الاســطلاعية للبحـث: تـم إجـراء التجربـة الاسـتطلاعية لبيئـة الـتعلم

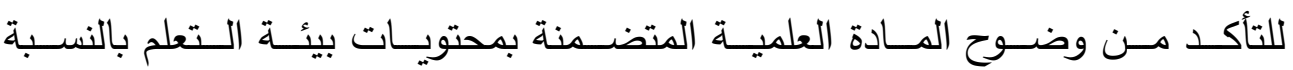

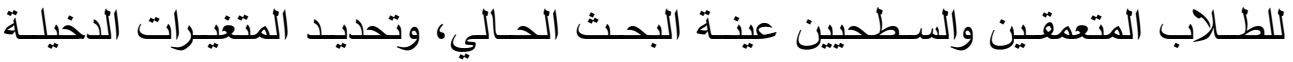
واسـتبعادها وكـذلك تحديـد نـواحي القصـور في بيئة الـتعلم بحيـث يمكن تلافيهـا قبـل البـدء في تتفيـذ التجربـة الأساسـية، بالإضـافة إلى التحقـق مـن ثبـات أدوات القياس، كما كثفت عن صلاحية مواد المعالجة التجريبية (الدروس). 
نمط المراجعة الاكترونية (فردي، ثنائي، جماعي) في بيئة الفصول أ. هنادي محمد أنور التجربة الأساسية للبحث:

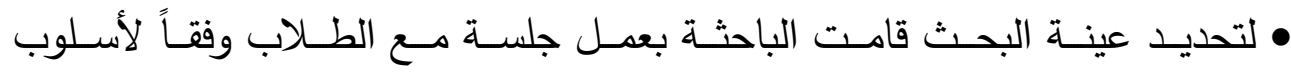

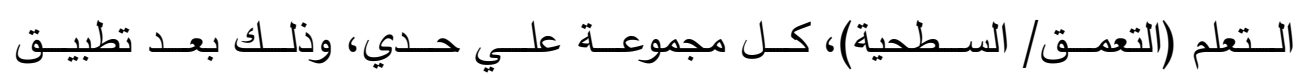

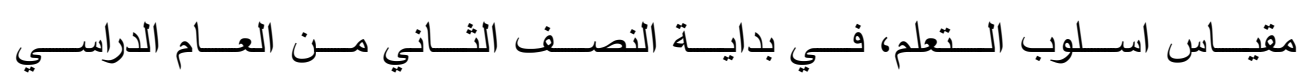

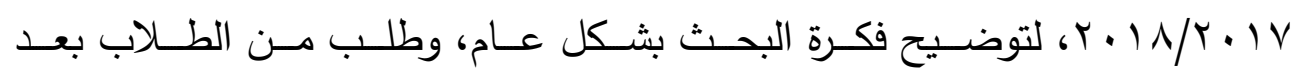

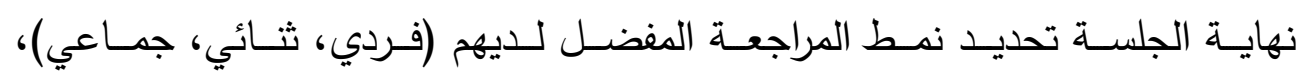

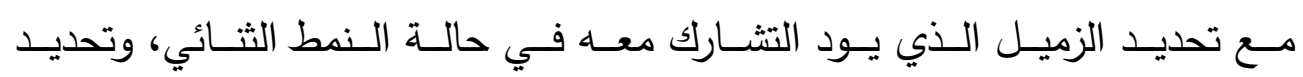

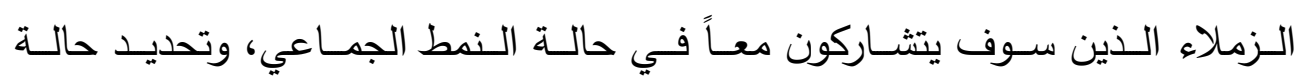

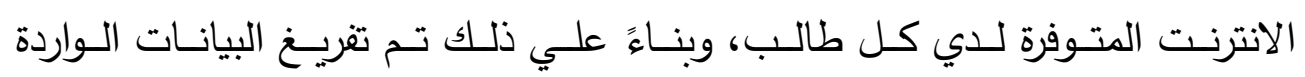
من الطلاب بخلاف طلاب العينة الاستطلاعية-

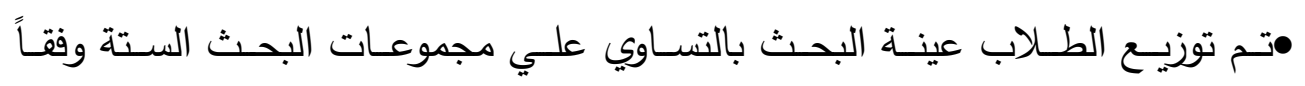

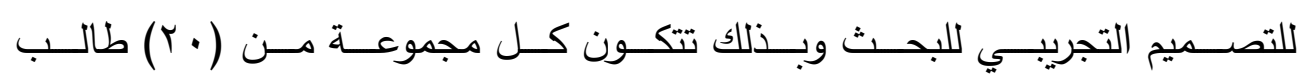

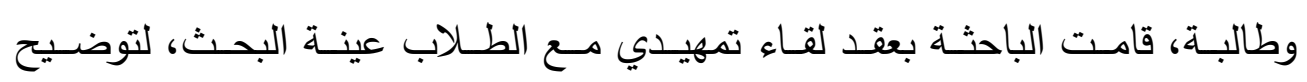

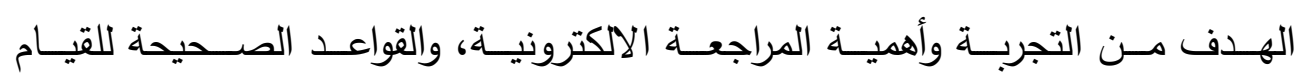

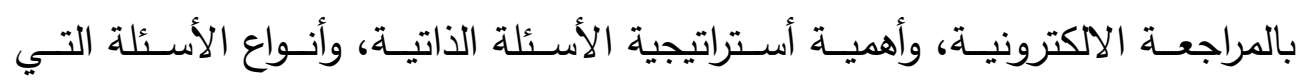

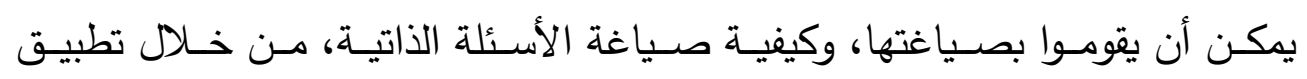

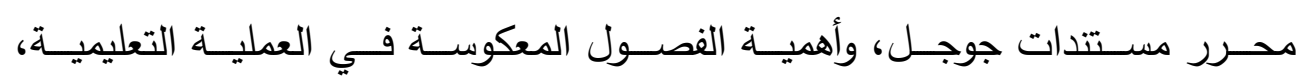

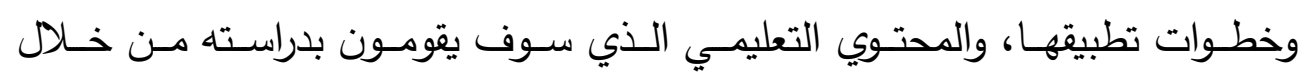

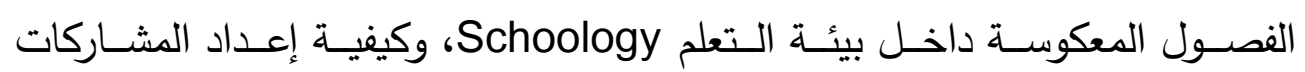
والتعليقات الجيدة وطرح الأسئلة الجيدة. التطبيق القبلي لأداة البحث:

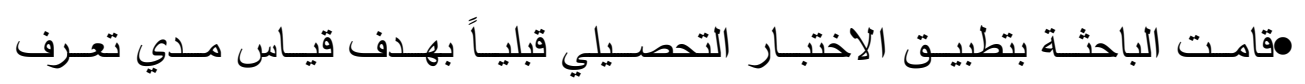

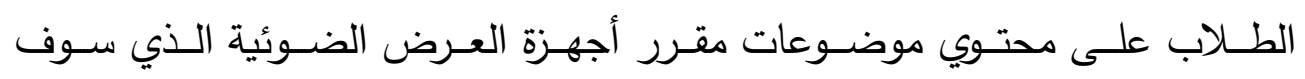




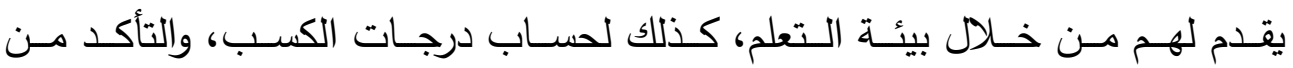
تكافؤ المجموعات التجريبية في التحصيل. •تــدريس موضـوعات المقـرر : بــدأت الباحثـة فــي تــدريس موضــوعات مقـرر

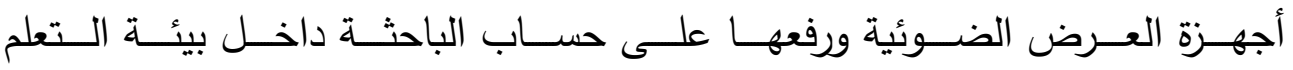
"Schoology " الالكترونية

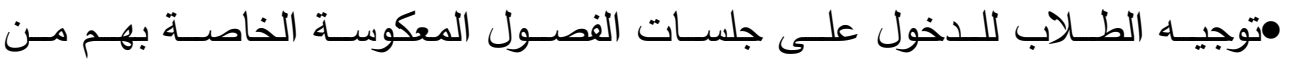

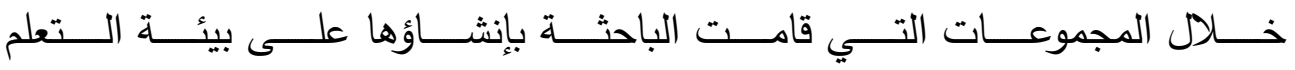
"Schoology"، ثــم الـدخول علـى جلسـات المراجعـة الالكترونيــة مــن خــلال تطبيـق محسـرر مســتندات جوجـل Docs Google وفقــاً للتصــميم التجريبـي للبحث.

\section{التطبيق البعدي لأدوات البحث:}

•بعـد انتهـاء جميـع المجموعـات مـن دراسـة المحتـوي الرقمـي وقيـامهم بالمراجعـة الالكترونيـة، تـم تطبيـق الاختبـار التحصـيلي بعـدياً للســت مجموعـات، وتـم إجـراء

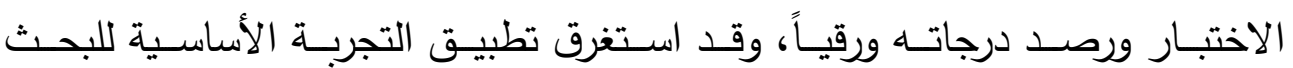

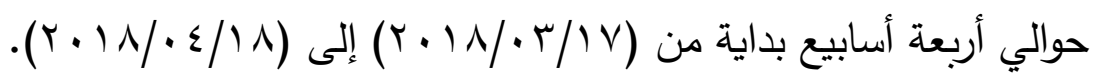

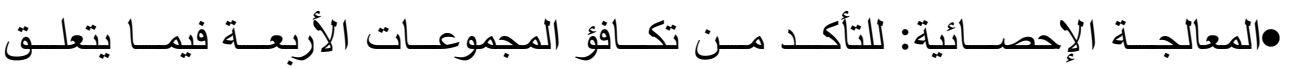

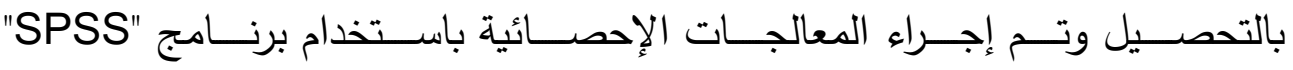
الإصدار العاشر، وذلك لأستخدام اسلوب تحليل التباين ثنائي الاتجاه. وفيما يلي عرضاً للنتائج التي أسفر عنها التحليل الإحصائي وفق أسئلة البحث وفروضه:

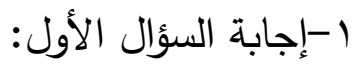


نمط المراجعة الاكتررونية (فردي، ثنائي، جماعي) في بيئة الفصول أ. هنادي محمد أنور

ينص السؤال الأول علي:"ما صورة بيئة الفصل المعكوس الملائمسة لاستخدام

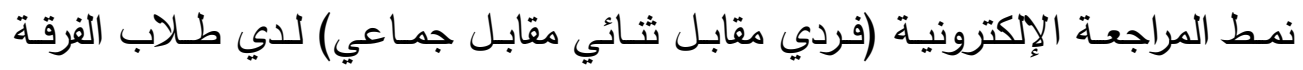

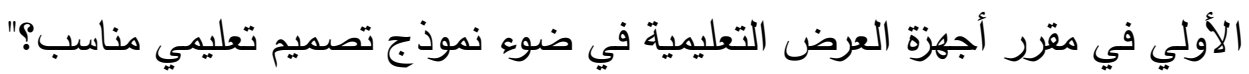

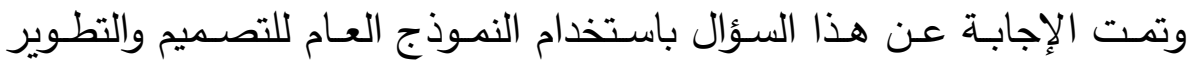

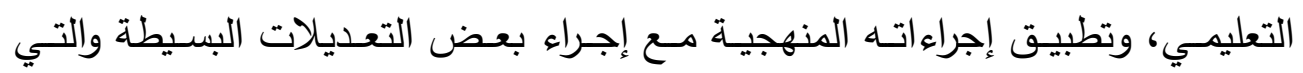

تتناسب مع طبيعة البحث الحالي.

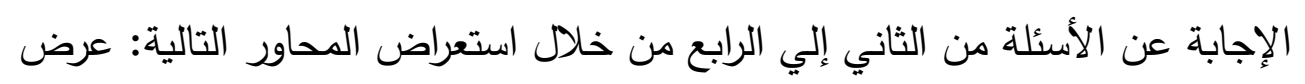

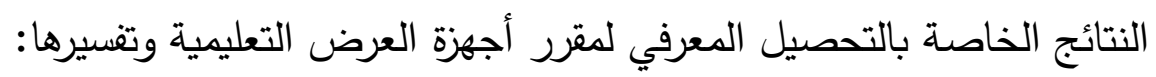

أ.الاحصاء الوصفي للتحصيل المعرفي لمقرر أجهزة العرض التعليمية:

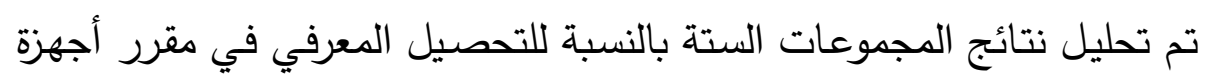

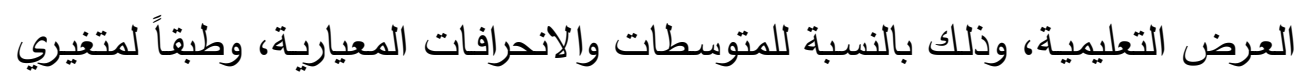

البحث الحالي، وجدول (r) يوضح نتائج هذا التحليل.

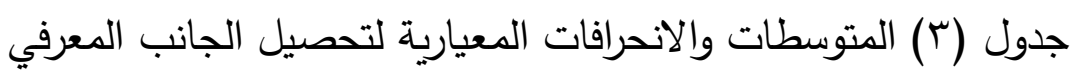

المرتبط بمقرر أجهزة العرض التعليمية.

\begin{tabular}{|c|c|c|c|c|c|}
\hline المتوسطات & \multicolumn{3}{|c|}{ نمط المراجعة } & \multirow{2}{*}{\multicolumn{2}{|c|}{ المجموعة }} \\
\hline الطرفية & الجماعي & الثنائي & الفردي & & \\
\hline $\begin{array}{l}r, r=r \\
v, r q=\varepsilon\end{array}$ & $\begin{array}{l}r, r=0 \\
r, r=0\end{array}$ & $\begin{array}{l}\varepsilon, \cdots= \\
1, \wedge \varepsilon=\varepsilon\end{array}$ & $\begin{array}{l}r 1,90= \\
1, V r=\varepsilon\end{array}$ & طحي & \multirow{4}{*}{ الأسلوب } \\
\hline $\begin{array}{l}r \vee, 1 \wedge=\beta \\
\wedge,\rceil 0=\varepsilon\end{array}$ & $\begin{array}{l}r, 0.0= \\
r, 1.1\end{array}$ & $\begin{array}{l}\varepsilon v, 70= \\
1,1 \wedge=\varepsilon\end{array}$ & $\begin{array}{l}r v, \varepsilon \cdot=r \\
r, \mid q=\varepsilon\end{array}$ & متعمق & \\
\hline$r \varepsilon, 19={ }_{p}$ & $\Gamma \varepsilon, \cdot=$ م & $\vee r, \wedge r=$ & $r \leqslant, \neg \Lambda=\beta$ & المتوسطات & \\
\hline$\wedge, \neg \wedge=\varepsilon$ & \urcorner,\rceil 0=\varepsilon$ & $\varepsilon, 1\rceil=\varepsilon$ & $r, \Gamma \wedge=\varepsilon$ & الطرفية & \\
\hline
\end{tabular}




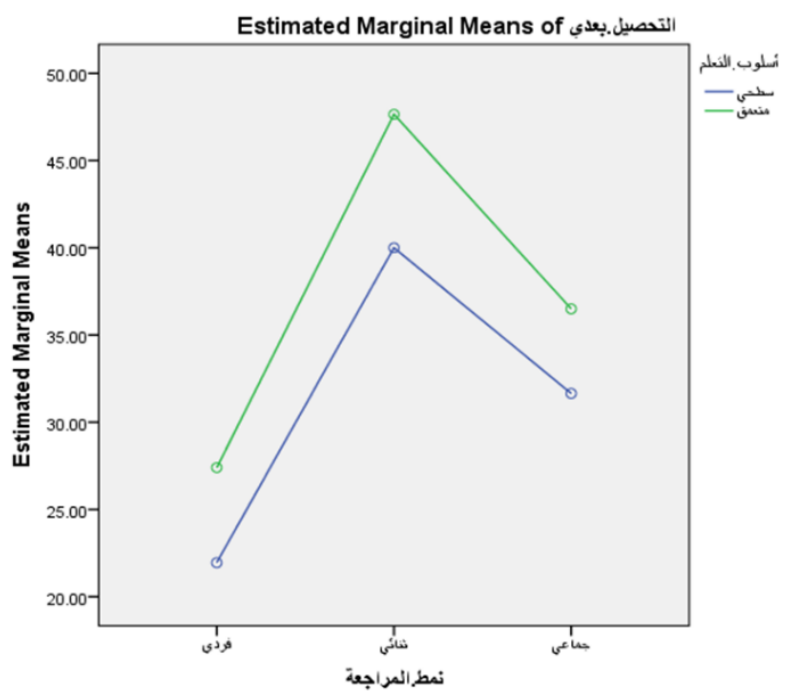

شكل (1) متوسطات درجات طلاب المجموعات التجريبية في التحصيل

المعرفي عند مراجعة المحتوي في بيئة الكترونية يرجع للتأثير الأساسي

للتفاعل بين نمط المراجعة الاككترونية وأسلوب التعلم.

يوضح جدول (r) نتائج الإحصاء الوصفي للمجموعات الست بالنسبة لتحصيل

الجانب المعرفي المرتبط بمقرر أجهزة العرض التعليمية، ويلاحظ البيانات التي يعرضها الجدول وجود تباين في متوسطات درجات الكسب بالنسبة لنمط المراجعة الالكترونية موضع المتغير المستقل الأول للبحث (الفردي مقابل الثنائي مقابل الجماعي)، حيث بلغ متوسط درجات الكسب في التحصيل لمجموعة نمط المراجعة

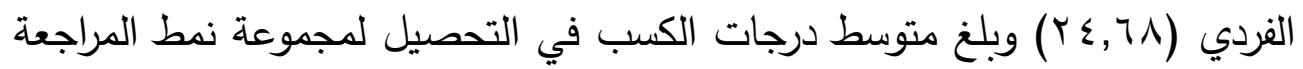
الثنائي (r,یr,گ)، وبلغ متوسط درجات الكسب لمجموعة نمط المراجعة الجماعي ( ) • عـ)، بينما كان هناك فرق واضح بين متوسطي درجات الكسب بالنسبة للمتغير المستقل الثاني وهو أسلوب التعلم (التعمق مقابل السطحية)، حيث بلغ متوسط درجات الكسب في التحصيل لمجموعة أسلوب التعمق (YV,IN)، وبلغ متوسط درجات الكسب في التحصيل لمجموعة أسلوب السطحية ( • , (r). 
نمط المراجعة الاكتررونية (فردي، ثنائي، جماعي) في بيئة الفصول أ. هنادي محمد أنور

كما يلاحظ من البيانات التي يعرضها الجدول اختلاف متوسطات الهجموعات

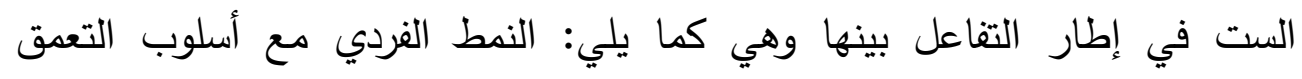

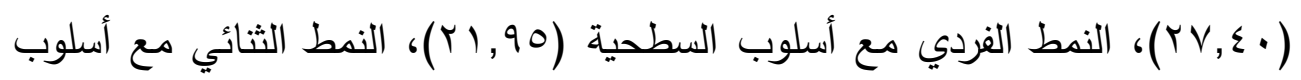
التعمق (

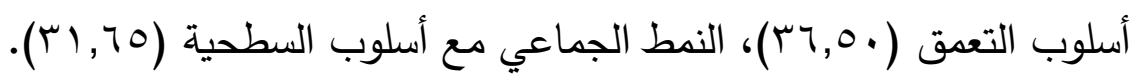

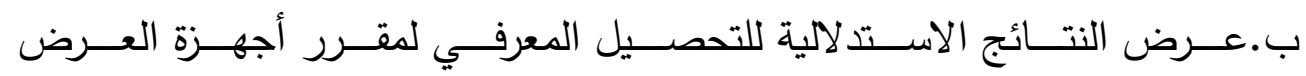

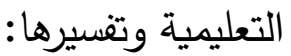
يوضح الجدول التالي نتائج التحليل ثنائي الاتجاه بالنسبة للتحصيل المعرفي ل ل لمقرر أجهزة العرض التعليمية.

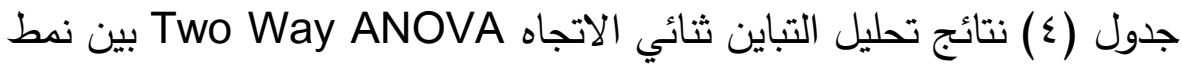

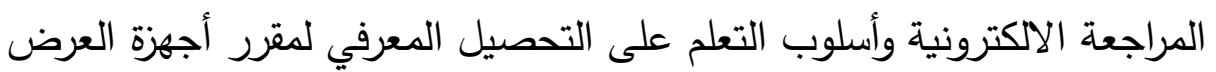
التعليمية

\begin{tabular}{|c|c|c|c|c|c|}
\hline الدلالة & قيمة "ف" & المربعات & الدرجة & المربعات & مصدر التباين \\
\hline 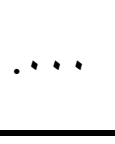 & $\Lambda \cdot 1, r \cdot \Lambda$ & 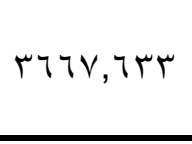 & r & VTTO,YTV & الاككترونية (متغيراً) \\
\hline$\cdots$ & $r r\{, T r)$ & $1 . v \varepsilon, \ldots 1$ & 1 & $1 \cdot v \varepsilon, \ldots 1$ & أسلوب التعلم \\
\hline. .1 & $\varepsilon, V \leqslant \wedge$ & rI,VRr & $r$ & $\varepsilon r, \leqslant T V$ & التفاعل (أxب) \\
\hline & & $\varepsilon, O \vee \wedge$ & $11 \varepsilon$ & or 1,10 . & خطأ التباين \\
\hline & & & 119 & $\wedge 9 Y \varepsilon, 09 Y$ & التباين الكلي \\
\hline
\end{tabular}


وبإستخدام نتائج جدول (ع) يمكن استعراض النتائج من حيث أثر المتغيرين المستقلين للبحث، والتفاعل بينهما علي ضوء مناقثة الفروض الثلاثة الأولي للبحث

\section{وهي كالتالي:

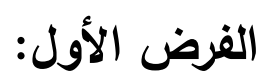

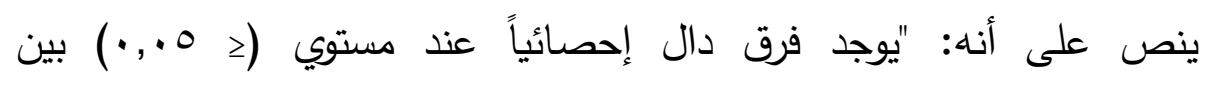
متوسطات درجات الكسب لطلاب المجموعات التجريبية في اختبار تحصيل الجانب المعرفي عند مراجعة المحتوي في بيئة الفصول المعكوسة يرجع للتأثير الأساس لاختلاف نمط المراجعة الالكترونية (الفردي مقابل الثنائي مقابل الجماعي)". وباستقراء النتائج في جدول (ع) في السطر الثاني، يتضح أنه هناك فرق دال إحصائياً فيما بين متوسطات درجات الكسب في التحصيل المعرفي نتيجة الاختلاف جاء في نمط المراجعة الاككترونية (الفردي مقابل الثنائي مقابل الجماعي). ولتحديد اتجاه هذه الفروق تم استقراء جدول (ع) ليتبين أن المتوسط الأعلي جاء لصالح المجموعة التجريبية التي قامت بالمراجعة ثنائيا، وبالتالي تم قبول الفرض هذاءن الأول.

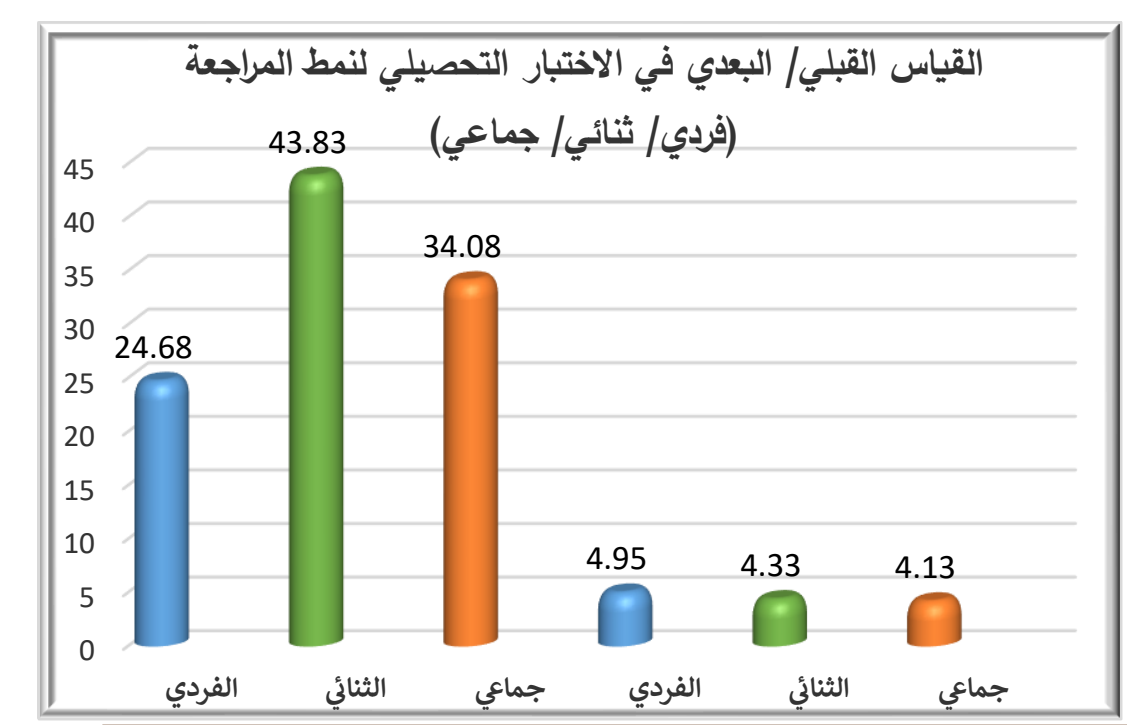


نمط المراجعة الاكترونية (فردي، ثنائي، جماعي) في بيئة الفصول أ. هنادي محمد أنور

شكل (Y) رسم بياني يوضح نتائج التحصيل المعرفي لمقرر أجهزة العرض

$$
\text { التعليمي لنمط المراجعة (فردي، ثنائي، جماعي) }
$$

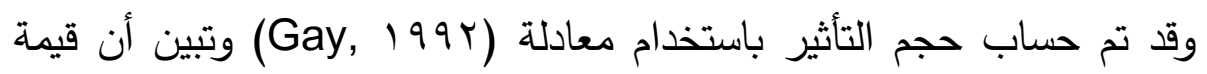

حجم تأثير المراجعة الاككترونية على التحصيل المعرفي للطلاب قد بلغت (T) ب, (0).

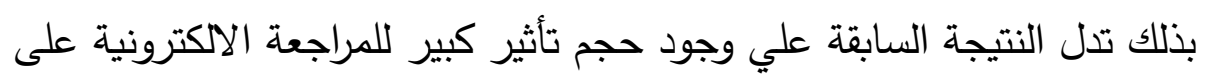
التحصيل المعرفي المرتبط بمقرر أجهزة العرض التعليمية. تفسير نتائج الفرض الأول:

وتشير هذه النتيجة إلى أن الطلاب الذين قاموا بالمراجعة الإلكترونية في بيئة

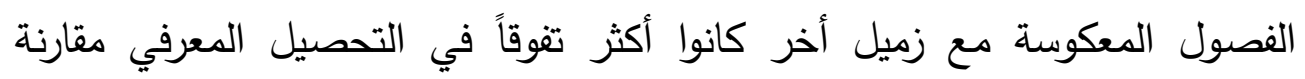

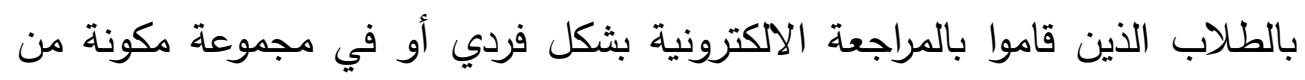

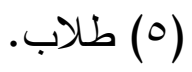

\section{وترجع الباحثة هذه النتيجة إلى الأسباب التالية:}

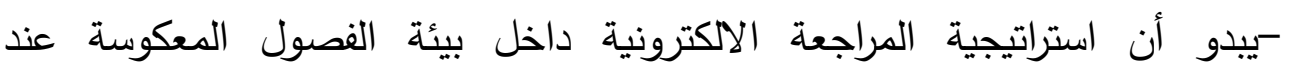

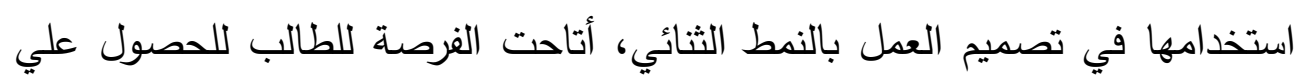

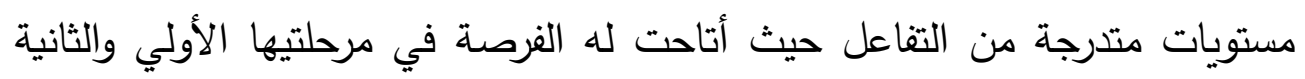
وهي مرحلة التفريد (قبل وأثناء التعلم) لحدوث تفاعل عميق مع العناصر الأساسية

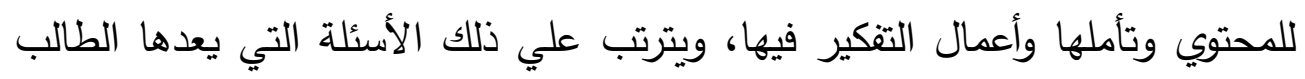

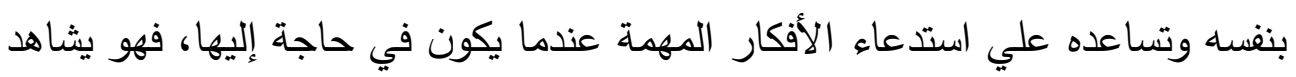

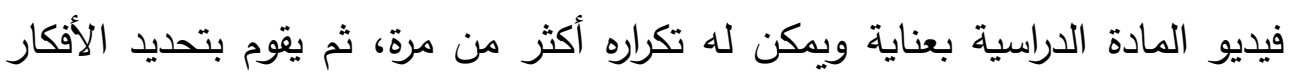

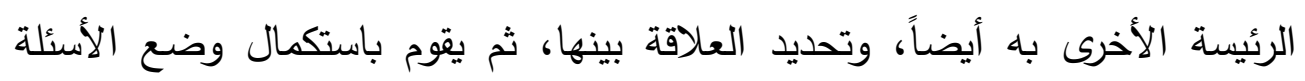

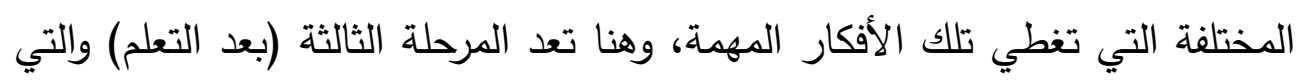

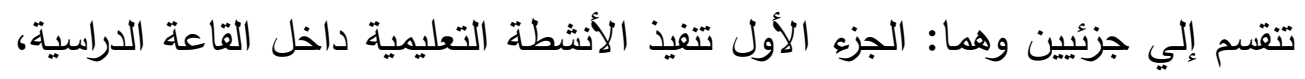
أما الجزء الثاني إجراء المراجعة الالكترونية، وفي هذه المرحلة يعمل الطالب مع زميله لالهيل 
حيث يحدث تكامل بين الطالبين المتشاركين حيث يكمل كل طالب ما فقده زميله من معارف ومهارات مهمة يمكن أن تقيد في أثثاء تنفيذ المهمة بشكل أفضل سواء كانت المهمة تتفيذ الأنشطة أو المراجعة الالكترونية، كذلك يشتمل العمل بشكل ثنائي بين الطالبين علي تبادل للتغذية الراجعة بواسطة المراجعات المنتجة لهم، كذلك شجع العمل بين الطالبين علي إجراء المناقثات وتبادل الآراء والأفكار مما ساعدهم علي تثبيت المعلومات وسهولة استرجاعها لدي الطلاب، كذلك ساعدت البيئة الالكترونية التي تم فيها العمل بشكل ثنائي بإمكانياتها المتعددة في تسهيل العمل الثنائي. وهذه النتيجة تتفق مع نتائج مجموعة من الدراسات والبحوث وتوجهات بعض النظريات التي أشارت جميعاً إلي تفوق أنشطة التعلم الثنائي بصفة عامة مقارنة بأنشطة التعلم الفردي والتعلم في مجموعات، حيث أشارت دراسات كل من Hui Chiu, ؛ Kimmerle\& Joachim, Y. . 9 ؛ Meskill, \& Anthony, Y...0)

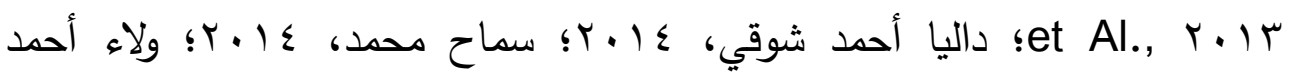
عباس، 10 • ب؛ أحلام دسوقي، 10 • ب؛ علي عبد القادرالثوربجي، 10 • ب؟ نورهان

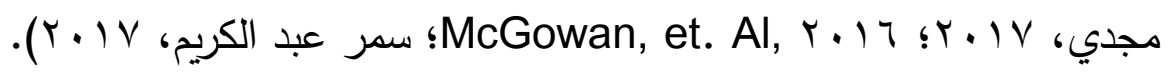

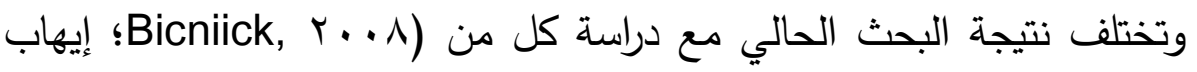

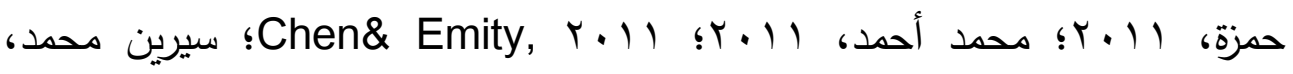

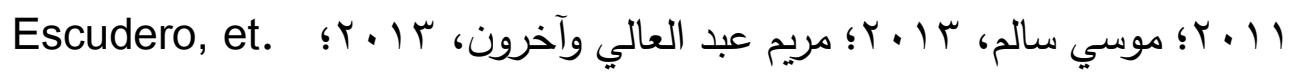

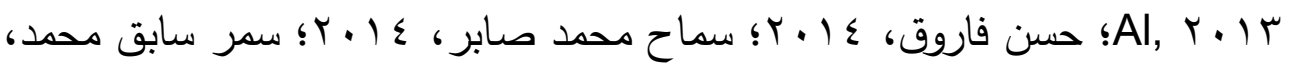

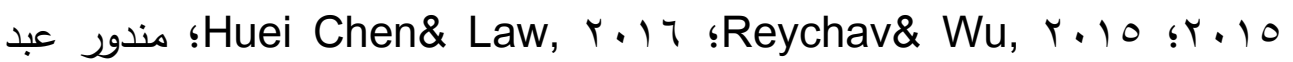

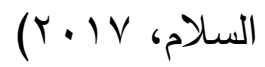

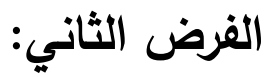
ينص على أنه: " يوجد فرق دال إحصائياً عند مستوي (2 0 . . • ) بين متوسطي درجات طلاب المجموعتين التجريبيتين في اختبار التحصيل المعرفي عند مراجعة \& 1 
نمط المراجعة الاكتررونية (فردي، ثنائي، جماعي) في بيئة الفصول أ. هنادي محمد أنور المحتوي في بيئة الكترونية يرجع للتأثير الأساسي لاختلاف أسلوب التعلم (التعمق مقابل السطحية). وباستقراء النتائج (في جدول \&) في السطر الثاني، يتضح أن هناك فرق دال

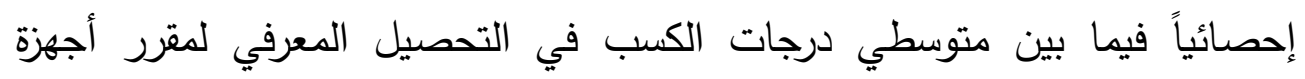

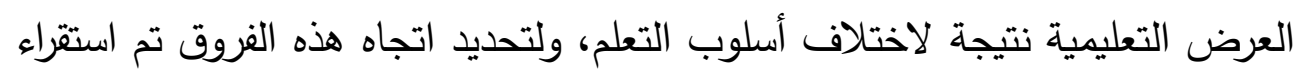

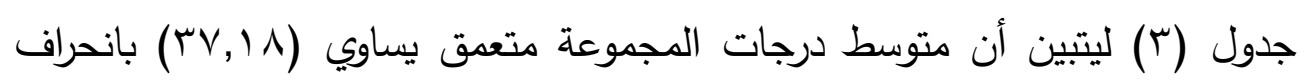

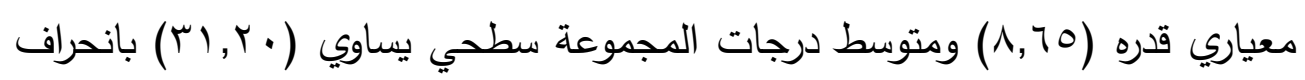

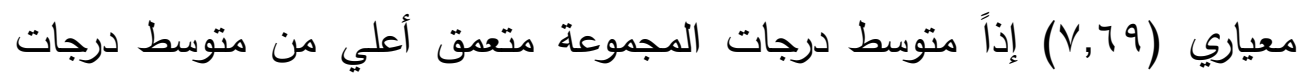
المجموعة سطحي، بالتالي هناك فروق جوهرية عند مستوي دلالة (2 ه . . •) لصالح مجموعة المتعقق وبالتالي تم قبول الفرض الثاني هنئ فروق جرهبة

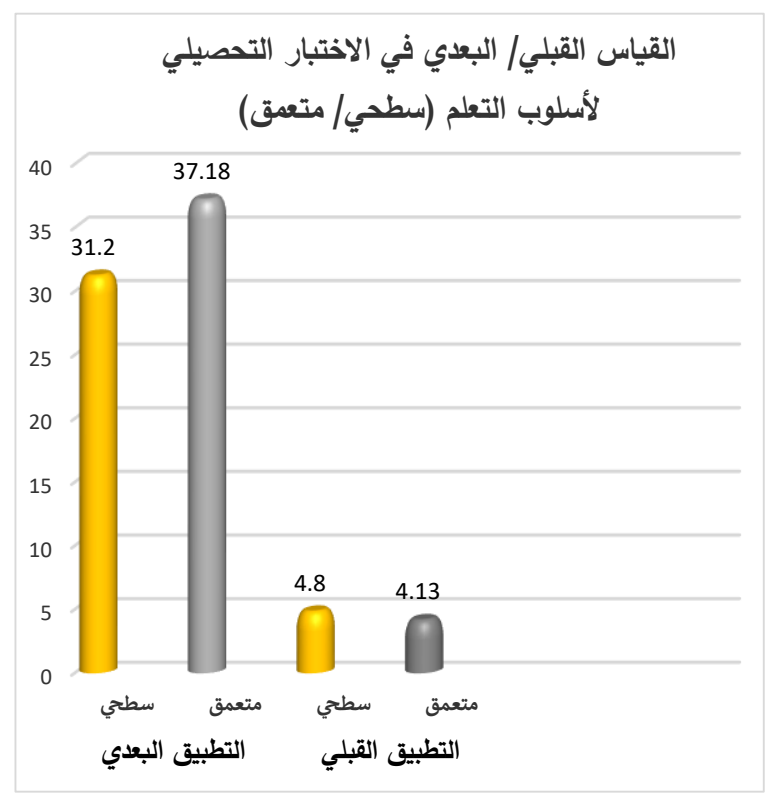

شكل (r) رسم بياني يوضح نتائج التحصيل المعرفي قبلي وبعدي لمقرر أجهزة

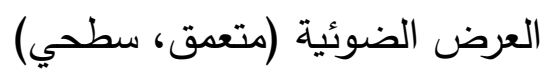


تقوق المتعمقين على السطحين في الجانب المعرفي لمقرر أجهزة العرض الضوئية وترجع الباحثة ذلك إلى الخصائص العديدة التي تميز بها المتعمقين عن السطحين ومنها: - يتسم أصحاب أسلوب التعقق بالتركيز علي عدد أكبر من عناصر المحتوي، بحيث يشمل انتباههم علي قدر أوسع من المثيرات المحيطة بهم التي يتعرضون لها. -أصحاب أسلوب التعلم المتعمق يتعلمون من أجل الفهم ويتفاعلون مع ما يتعلمون، ويربطون خبراتهم بالمعرفة السابقة؛ لذا يصلون إلى مستوي عال من التحصيل الدراسي؛ أما أصحاب أسلوب التعلم السطحي يتقبلون الأفكار كما هي دون معالجة للمعلومات أو الأفكار ويعتمدون على التركيز على الأجزاء البسيطة وتخطي الأجزاء

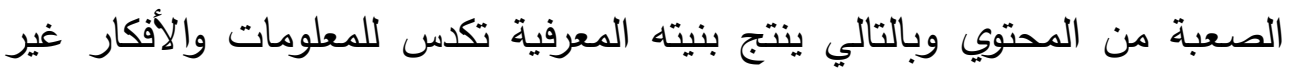
المترابطة مما يؤثر بالسلب على التحصيل الدراسي. -الطلاب الذين يتبنون مدخلاً عميقاً يبذلون محاولات جدية لتحويل الأفكار الجديدة إلي بنيته المعرفية الشخصية، وإنهح يميلون إلي العمل وفقاً للنمط العام التالي: يسعون إلي فهم المادة بأنغسه، يتفاعلون بشدة وبشكل ناقد مع المحتوي، يربطون الأفكار بالمعرفة والخبرة السابقة، يستخدمون مبادئ منظمة لربط الأفكار، يربطون الأدلة والاستتتاجات، يفحصون منطق الحجج، بينما نجد أن التعلم السطحي يتضدن ببساطة ملامسة سطح المادة موضوع الدراسة دون التعمق في المادة، والطلاب الذين يتبنون مثل هذا المدخل السطحي يميلون إلي العمل وفقاً للنمط العام التالي: يركزون تماماً علي متطلبات التقييم، يقبلون المعلومات والأفكار بشكل سلبي، يحفظون الحقائق والإجراءات بشكل روتيني، يهملون المبادئ أو النماط الموجهة، يفشلون في تأمل الغرض أو الاستراتيجية التحتية. 
نمط المراجعة الاكترونية (فردي، ثنائي، جماعي) في بيئة الفصول أ. هنادي محمد أنور

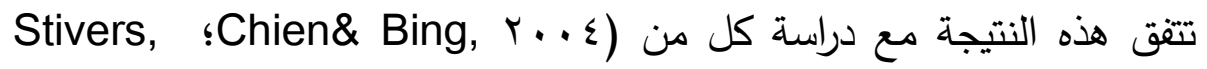
Pryor And Bitter, ؛Yildiriem, r... ؛ Pellegrinos, r... ؛Tinajero et al, r.lr ؛Lam et al., r.ll ؛Fund, r.l. r...

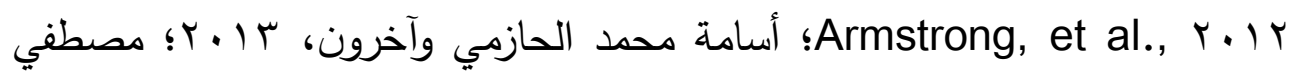

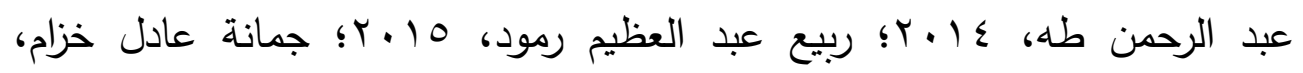

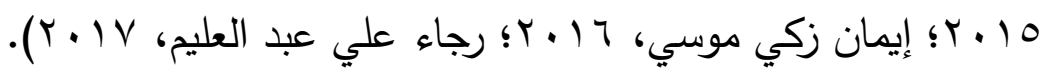

$$
\begin{aligned}
& \text { الفرض الثالث: }
\end{aligned}
$$

ينص على أنه: " يوجد فرق دال إحصائياً عند مستوي (2 0.,.) بين

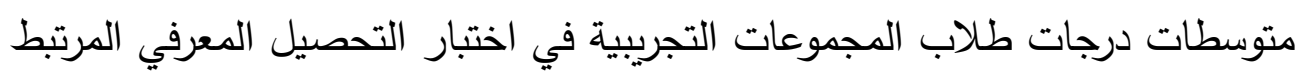

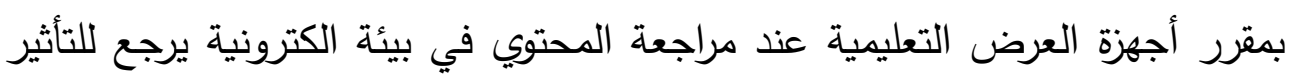
الأساس للتفاعل بين نمط المراجعة الالكترونية (فردي مقابل ثنائي مقابل جماعي) وأسلوب التعلم (التعمق مقابل السطحية)". وباستقراء النتائج (في جدول؛) في السطر الثالث يتضح أن هنالك فروقاً دالة

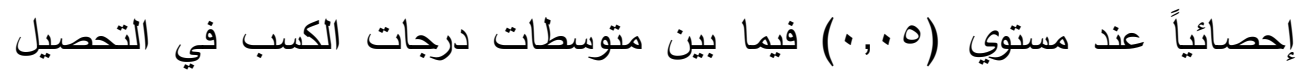
المرتبط بمقرر أجهزة العرض الضوئية نتيجة التفاعل بين نمط المراجعة الآكترونية (فردي مقابل ثنائي مقابل جماعي) وأسلوب التعلم (التعمق مقابل السطحية).

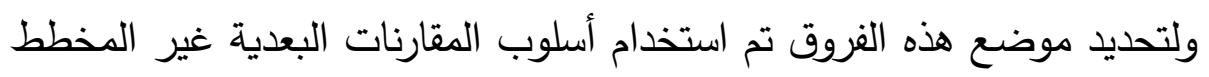
لها "Post Hoc Follow UP " وهي تستخدم للكثف عن مواضع الفئ الفروق بين

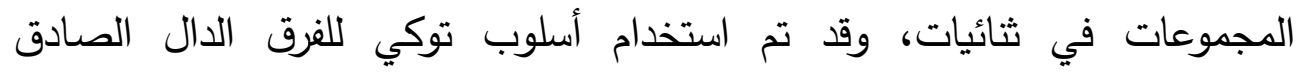
(Turkey's Honestly Significant Difference (H. S. D)

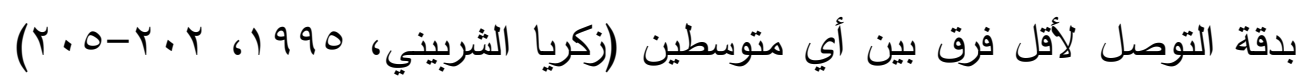

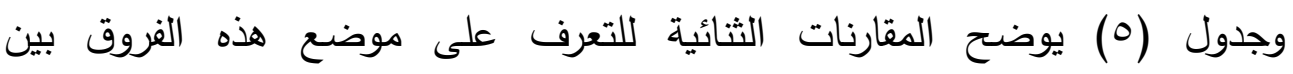


المجموعات الست الناتجة عن التفاعل الثنائي بين نمط المراجعة الالكترونية وأسلوب التعلم.

جدول (0) المقارنة الثنائية بين المجموعات الست الناتجة عن التفاعل الثنائي بين نمط المراجعة الالكترونية وأسلوب التعلم في تحصيل الجانب المعرفي

\begin{tabular}{|c|c|c|c|c|c|c|c|c|}
\hline $\begin{array}{l}3 \\
y_{2} \\
y \\
y\end{array}$ & 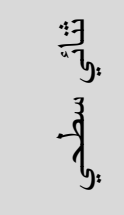 & $\begin{array}{l}\text { के } \\
\text { y. } \\
\text { y. }\end{array}$ & $\begin{array}{l}3 \\
y \\
y . \\
3 \\
3 \\
3\end{array}$ & 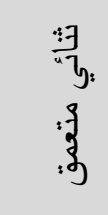 & 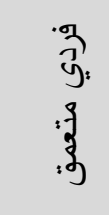 & $\begin{array}{l}\bar{g} \\
3 \\
3 \\
3 \\
3\end{array}$ & $\frac{y}{\frac{9}{1}}$ & $\begin{array}{l}\frac{j}{2} \\
\text { 司. }\end{array}$ \\
\hline & & & $9,1$. & $r \cdot, r_{O}$ & & $Y V, \varepsilon$. & $r$. & فتعمق \\
\hline & & & 11,10 & & & $\leqslant V, 70$ & $r$. & ثتعمقي \\
\hline & & & & & & rч, O. & $r$. & جمعمق \\
\hline$q, \vee$. & $1 \wedge, .0$ & & $1 \leqslant, 00$ & $r_{0, V}$. & $0, \leqslant 0$ & r 1,90 & $r$. & فردي \\
\hline \multirow[t]{2}{*}{$\Lambda, r_{0}$} & & & $r, 0$. & $v, 10$ & $1\}, T$. & $\varepsilon, \cdots$ & $r$. & شطنيائي \\
\hline & & & $\varepsilon, \wedge 0$ & $17, \ldots$ & $\varepsilon, Y_{0}$ & $\mu, 70$ & $r$. & جماعي \\
\hline
\end{tabular}

يوضح شكل (r) تمثيل بياني للتفاعل بين المتغيرين المستقلين في التحصيل الدراسي ويلاحظ أن النمط الثنائي للمراجعة الاككترونية أعلي فاعلية علي التحصيل الدراسي البعدي بالمقارنة بالنمط الفردي والجماعي، بينما كان أسلوب التعلم العميق أعلي في التحصيل الدراسي في مقابل أسلوب التعلم السطحي، كما يلاحظ تفاعل دال إحصائياً للمتغيرين المستقلين نمط المراجعة الالكترونية (الفردي مقابل الثنائي مقابل 
نمط المراجعة الاكترونية (فردي، ثنائي، جماعي) في بيئة الفصول أ. هنادي محمد أنور

الجماعي)، وأسلوب التعلم (العيق مقابل السطحي) علي التحصيل الدراسي البعدي

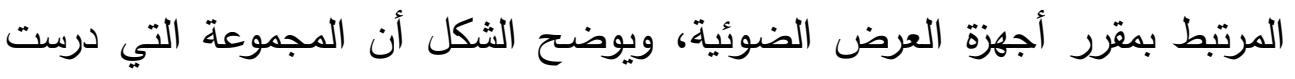

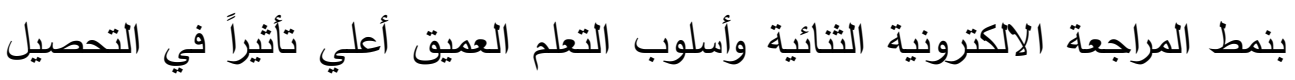

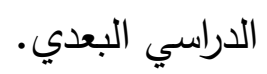

وبالتالي تم قبول الفرض الثالث، وكما يتضح من النتائج التي يلخصها جدول

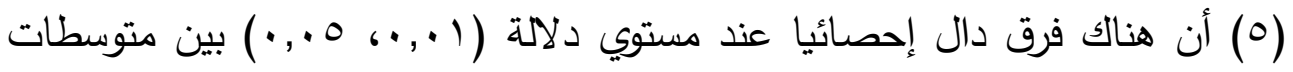

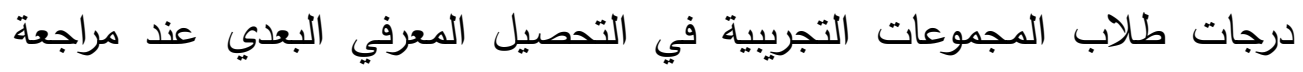

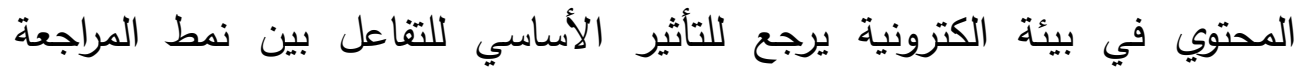
الالكترونية (الفردي مقابل الثائي مقابل الجماعي) وأسلوب التعلم (المتعمق مقابل

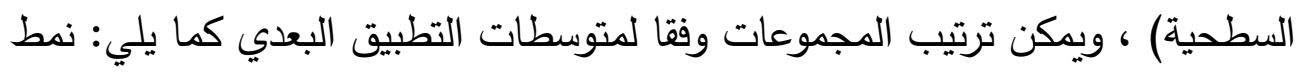

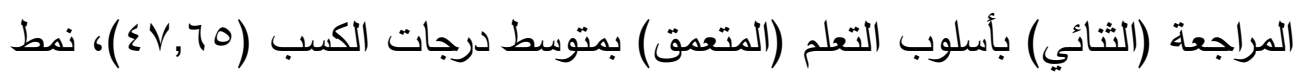

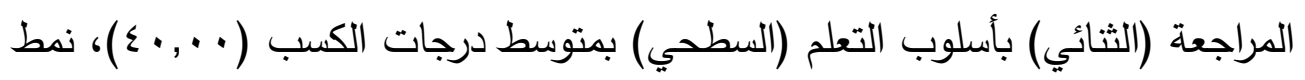

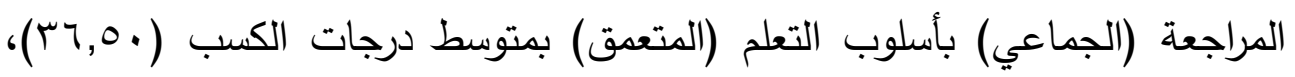

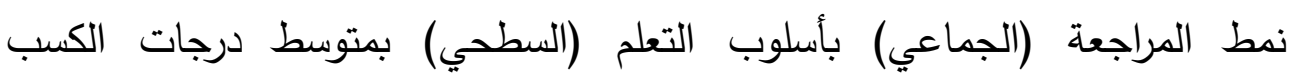

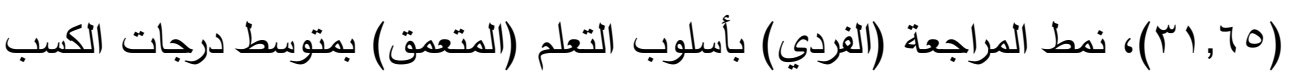

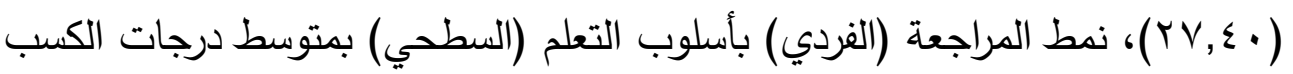
$\cdot(r), 90)$

\section{تفسير نتائج الفرض الثالث:}

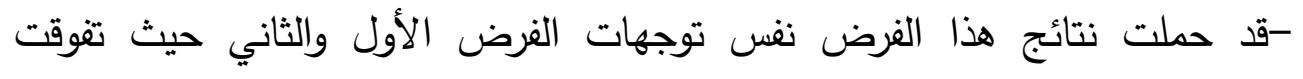

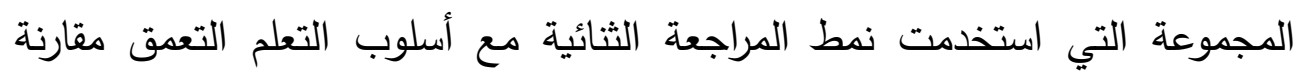

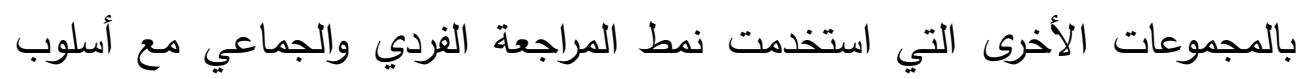
التعلم السطحي، وعلى ذلك يجب مراعاة هذه النتيجة عند تصميم بيئات المراجعة 
الالكترونية داخل الفصول المعكوسة خاصة إذا ما دعمت نتائج الدراسات والبحوث المستقبلية هذه النتيجة.

-وترجع الباحثة أيضاً هذه النتيجة إلى ذات الأسباب التي فسرت تفوق المراجعة الثنائية في الفرض الأول، وتفوق أسلوب التعلم المتعمق في الفرض الثاني. وتتفق هذه النتيجة مع دراسة (Felder\& Silverman, 1991) والتي أشارت إلي وجود علاقة بين أسلوب التعلم، والتعلم الالكتروني، فأساليب التعلم تعمل كمؤشرات ثابتة نسبياً لكيفية تفاعل الطالب واستجابته مع بيئة التعلم الاككتروني.

\section{توصيات البحث:}

ومن خلال النتائج التي توصل إليها البحث الحالي يمكن استخلاص التوصيات

التالية: •الإفـادة من نتائج البحث الحالي علي المستوي التطبيقي، إذا مـا توصلت البحوث المستقبلية لنفس نتائج البحث الحالي. •استخدام نمط ثنائي المراجعـة الالكترونيـة لأنـه أكثر إنسـاماً وتجانسـاً للعمل معاً بشـكل أكبر مـن النمط الجمـاعي، نظـراً لتقليل عامـل الصـراعات التي تحدث بـين الطلاب نتيجة زيادة عدد أفراد المجموعة. •هذا بالإضافة إلى أنه في نمط ثنائي المراجعة الالكترونية يتوافر عامل المرونة في تبادل وتوزيع الأدوار داخل مجموعة التفاعل مما يساعد علي تبادل المعرفة والخبرة التي يمتلكونها بشكل أكثر فعالية.

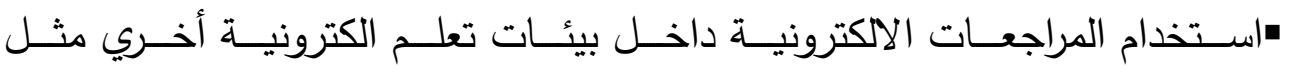
(....Google Plus ،Easy Class ،Edomodo) r-مقترحات ببحوث مستقبلية: •أقتصـر البحـث الحسالي علي تتـاول أثر متغيراتهـ المستقلة علي طـلاب المرحلـة الجامعية، لذلك فمن الممكن أن تتناول البحوث المستقبلية هذه المتغيرات في إطار 
نمط المراجعة الاكترونية (فردي، ثنائي، جماعي) في بيئة الفصول أ. هنادي محمد أنور مراحل تعليمية أخري، فمن المككن اختلاف النتائج نظراً لاختلاف العمر ومستوي

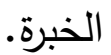

سقدم البحث متغيراتـه مـن خـلال بيئة الـتعلم الالكترونيـة Schoology ومحـرر

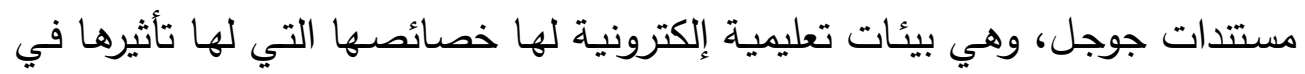
نتائج البحث لذلك فمن الممكن للبحوث المستقبلية أن تتناول نفس المتغيرات المستقلة

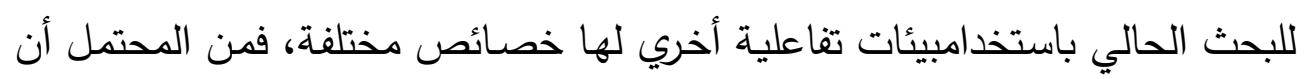
تأتي هذه البحوث بنتائج مختلفة عن البحث الحالي. 


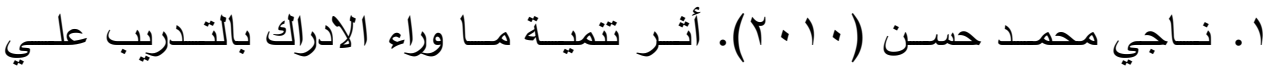
الأسـئلة الذاتيـة في الفهـم وإدارة الـذات لطـلاب الجامعـة، مجلـة كليـة التربيـة، جامعة عين شمس، ع ع ז، جr.

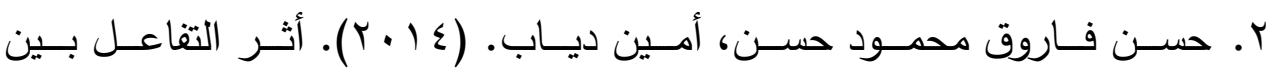
أســلوب التـدريب ونمــط الـتعلم فـى بـرامج التـدريب مــن بعـد فـى تتميـة

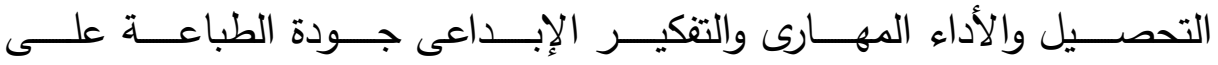
المنسـوجات لـدى طــلاب شــعبة التربيــة الفنيــة بكليـات التربيــة، دراســات عربية في التربية وعلم النفس، السعودية، ع (T0). r. سـيرين محمــ صـبحي أبـو كويـك. (11 • (1). أثر التـدريس بالمجموعـات الكبيـرة والمجموعـات الصـغيرة والتعليم الفـردي في تحصـيل طالبـات الصـف فئس

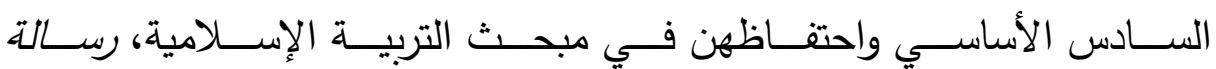
ماجستير، كلية العلوم التربوية، جامعة الثرق الأوسط.

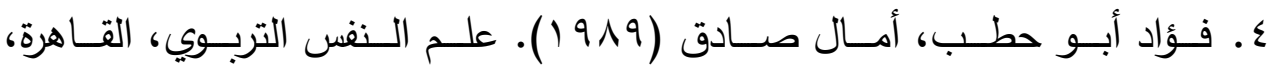
مكتبة الأنجلو المصرية.

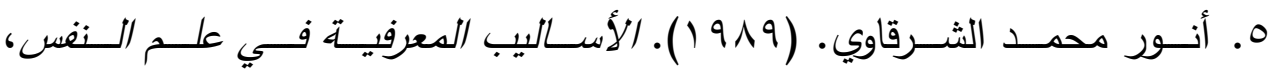

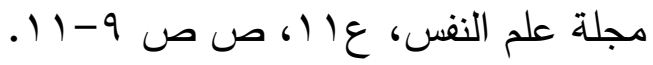

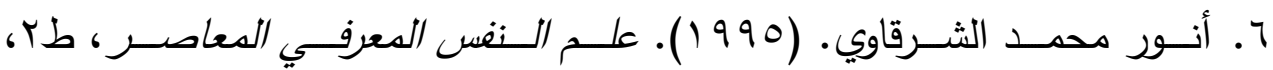
القاهرة، مكتبة الأنجلو.

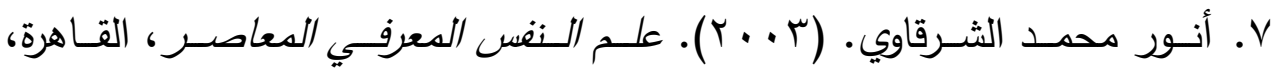
مكتبة الأنجلو المصرية.

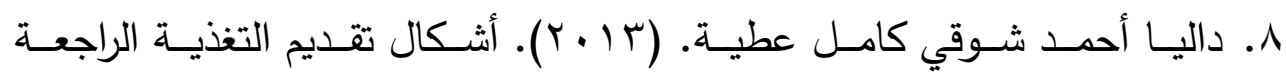
ببـرامج الكمبيـوتر التعليميـة (الوكيـل المتحــرك/ الـــص المكتـوب بتعليـق 
نمط المراجعة الاكترونية (فردي، ثنائي، جماعي) في بيئة الفصول أ. هنادي محمد أنور

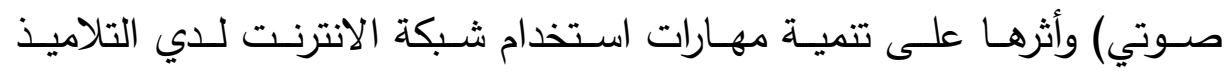

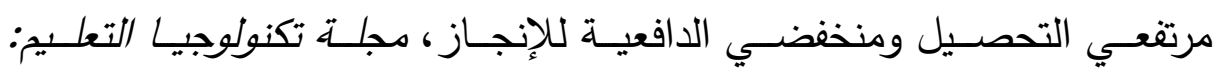

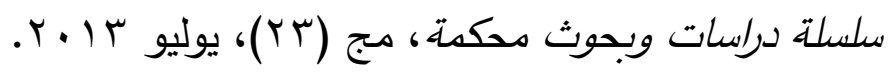

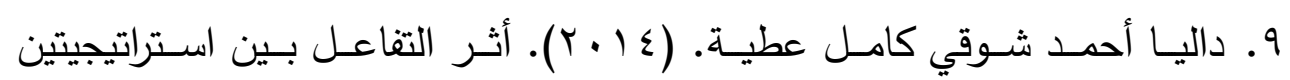

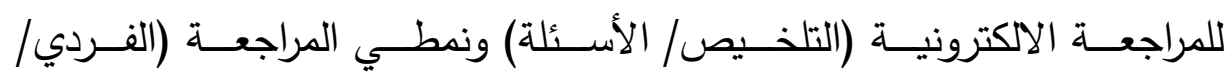

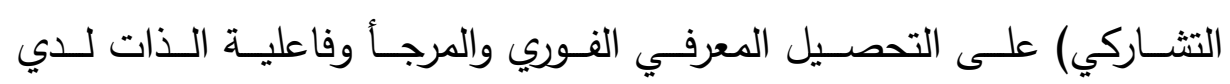

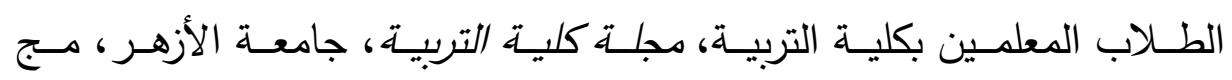
r. البن (10V)

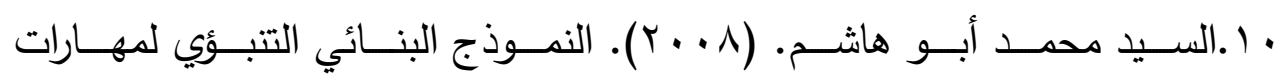

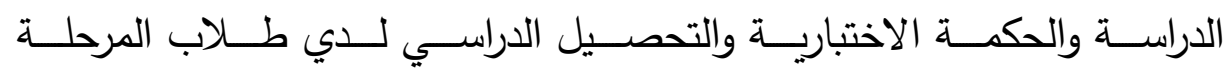

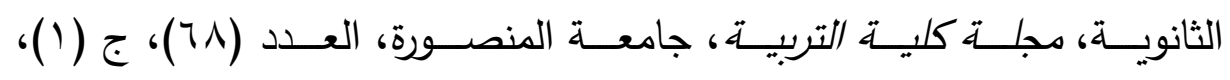
سبتمبر ^. . †.

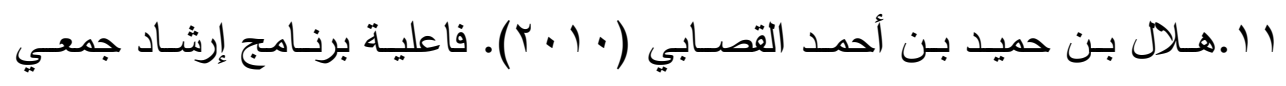

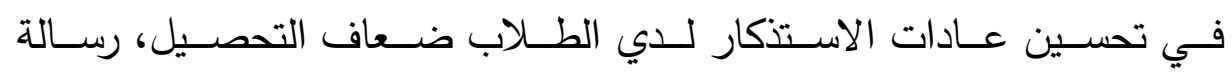
ماجستير ، كلية العلوم والآداب، جامعة نزوي.

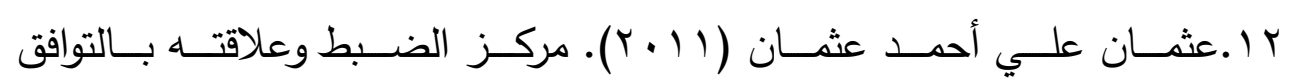

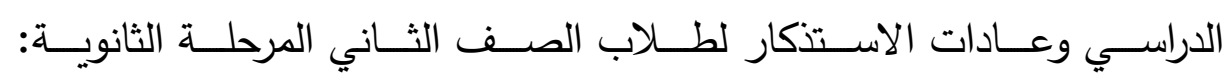

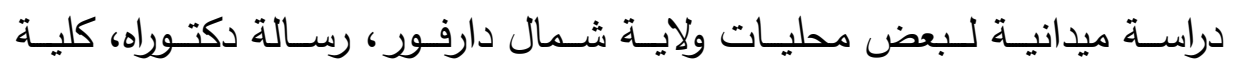
التربية، جامعة أم درمان الاسلامية.

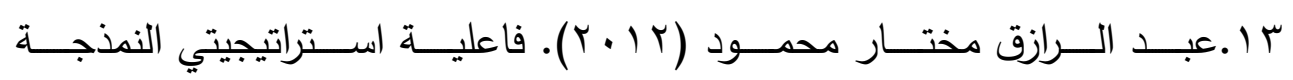

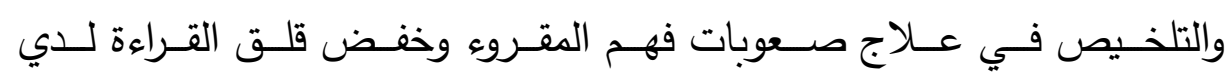

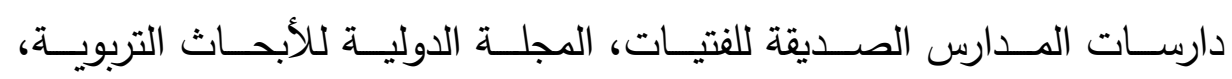

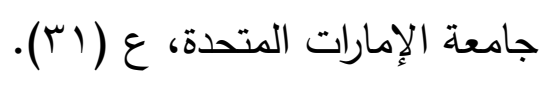




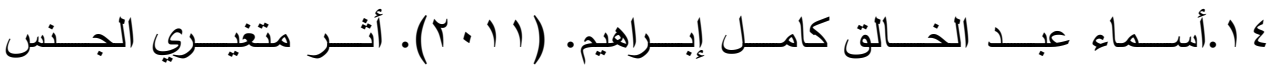

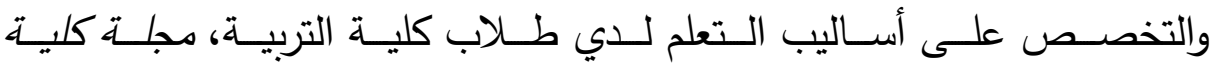

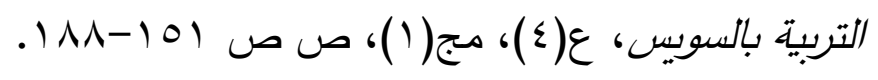

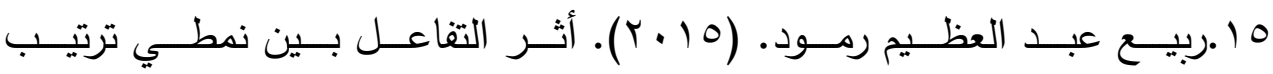
العناصــر البصــرية المصــاحبة للــص (التجــاور / التتــابع) فــي الوســائط

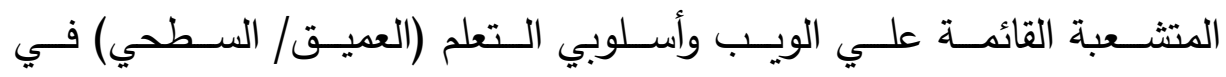

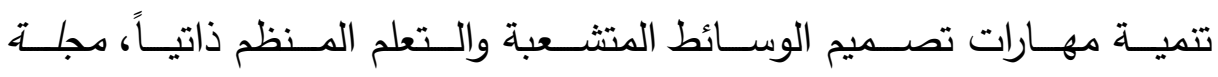

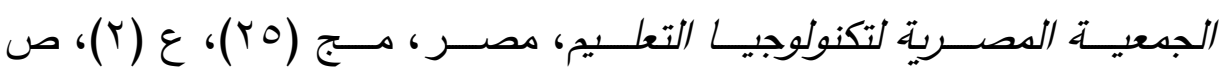
ص ص

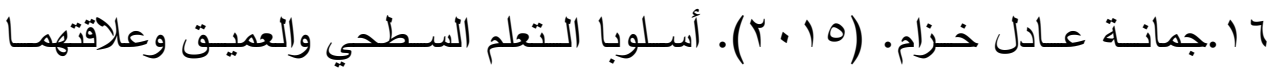

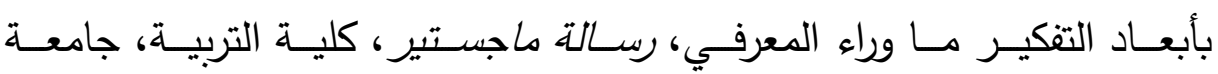
دمشق.

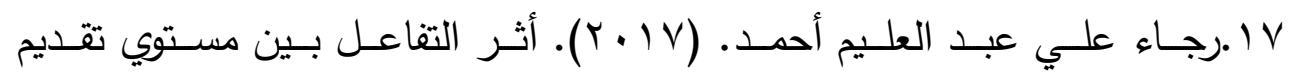
التغذيـة الراجعـة (تصــحيحية/ تفسـيرية) وأسـلوب الـتعلم (ســـي/ عميـق) في بيئـات الـتعلم الشخصـية علـي التحصـيل الدراسـي وكفــاءة الـتعلم لـدي

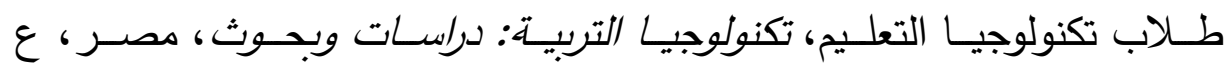

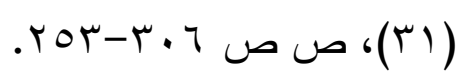

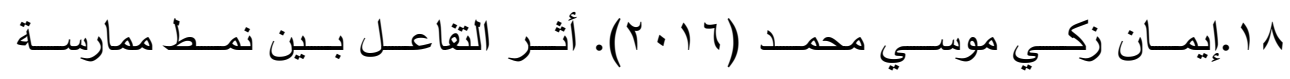
الأنثـطة (فردي/تعـاوني) وأسـلوب الـتعلم (العميق/الســـي) في بيئسة تعلـم

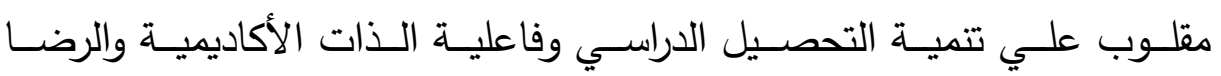

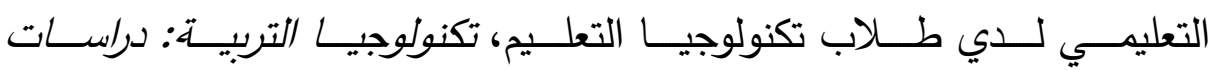

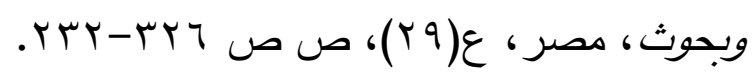


نمط المراجعة الاككترونية (فردي، ثنائي، جماعي) في بيئة الفصول أ. هنادي محمد أنور

19.Kiewra, K. A., DuBois, N. F., Christian, D., McShane, A., Meyerhoffer, M., \& Roskelley, D. (1991). Note-taking functions and techniques. Journal of educational psychology, $\lambda r(r), r \varepsilon \cdot$.

r..O'Neill, M. E. $(r \cdot 11)$. Automated use of a Wiki for collaborative lecture notes. Paper presented at the Proceedings of the ruth SIGCSE Technical Symposium on Computer ScienceEducation, St. Louis, Missouri.

r).King, A. (199r). Comparison of self-questioning, summarizing, and notetaking-review as strategies for learning from lectures. American Educational Research Journal, rq(r), r. r-rrr.

rr.Chen, C.\&, Emily, F. $(r \cdot 11)$. Experience-Based Language Learning through A Synchronous Discussion, ERIC, No: $E D \leqslant 9 \ldots 1 r r$.

rr.Haynes, J. M., McCarley, N. G., \& Williams, J. L. (Y.10). An analysis of notes taken during and after a lecture presentation. North American Journal of Psychology, I $\vee(1)$, 1 VO-114

r纟.Jeremy M. Haynes, Joshua L. Williams, Nancy G. McCarley, Erin Mullin, and Danielle Mears ( r.10). Textbook Learning Strategies in Traditional and 
Nontraditional Students, Delta Journal of Education, Armstrong State University, Volume o, Issue 1, Spring, Y. 10 ro.Wright, J. $(r \ldots \wedge)$. Intervention ideas for study skills/organization. Retrieved: $r \cdot 1 r / \cdot 1 / \cdot \varepsilon$, from:www.flipped learning.org.

rч.Taylor, L.\& Alber. R. $(Y \ldots r)$. The Comparative Effects of Modified of Self- Questioning Strategy and Story Mapping on the Reading Comprehension of Elementary Students with Learning Disabilities, Journal of Behvioral Educational, VOI. 1), No. r.

rv.McKeachie, W. J. (199६). Teaching tips: Strategies, research and theory for college and university teachers, Lexington. Mass: DC Heath \& Company.

r^.Armstrong, S. J., Peterson, E. R., \& Rayner, S. G. $(r \cdot \mid r)$. Understanding and Defining Cognitive Style and Learning Style: a Delphi Study in the Context of Educational Psychology. Educational Studies, rл( $\varepsilon)$, PP $\leqslant \leqslant q-\varepsilon 00$.

rq.Christine, C. (1999). The use of formativnd quizzes for deep learning, journal of computers and science education,.r., . $(\Gamma \varepsilon)$. 